\title{
A AULA DE CAMPO NO ENSINO DE GEOGRAFIA: ANÁlISE DA SUA PRÁTICA NA ESCOLA SECUNDÁRIA DE NAMIALO, PROVÍNCIA DE NAMPULA / MOÇAMBIQUE
}

\section{FIELD STUDY IN THE TEACHING OF GEOGRAPHY: ANALYSIS IN NAMIALO SECONDARY SCHOOL, NAMPULA PROVINCE / MOÇAMBIQUE}

\author{
João Ernesto NTUMUA ${ }^{1}$ \\ Eduardo Jaime BATA ${ }^{2}$ \\ Vandervilson Alves CARNEIRO ${ }^{3}$
}

\begin{abstract}
Resumo: Desde o desenvolvimento da geografia como ciência e disciplina escolar, a aula de campo tornou-se uma das práticas metodológicas bastante utilizadas pelos professores, não só como forma de consolidar a teoria, trabalhada em livros didáticos na sala de aula, mas também de aguçar o olhar e o pensamento crítico dos alunos. Neste artigo, buscamos analisar as práticas de aula de campo, enquanto estratégia metodológica no ensino de geografia na Escola Secundária de Namialo, partindo da experiência realizada com os alunos da $11^{\mathrm{a}}$ classe. A perspectiva teórica metodológica, assenta-se no materialismo histórico e na dialética como método de análise, pautado na abordagem qualitativa. Com efeito, a pesquisa envolveu 36 pessoas, dos quais 30 alunos, 5 professores e 1 Diretor Adjunto Pedagógico (DAP). Com base, na pesquisa bibliográfica e no trabalho de campo realizado na Vila de Namialo, junto à experiência acumulada ao longo de uma década de trabalho docente, é possível assinalar a articulação entre os aspectos teóricos e a realidade a ser observada no campo como parte de um único processo. De fato, o estudo comprovou que o ensino da geografia esteve e está vinculado à utilização de metodologias, ou seja, caminhos que auxiliem os alunos a adquirir experiências e conhecimentos do mundo no qual vivem. Por essa razão, a aula de campo constitui, na verdade, uma estratégia metodológica útil à teoria e a prática de ensino de geografia, pois permite, dentre outros aspectos, a construção de habilidades, atitudes e valores, assim como a ancoragem entre a teoria e a prática no ambiente escolar, base para o ensino de geografia.
\end{abstract}

Palavra-Chave: Aula de campo; Geografia Escolar; Ensino e Aprendizagem.

Abstract: Geography in the field of sciences has been a matter of investigation and debates, which end up with new paths and trends in regard to practices and teaching methodologies, however, field study as a teaching methodology is more distinguished methodologies adopted by teachers in the teaching of geography at school, in order to fund, complement and support the theoretical knowledge acquired during the classes. This study aims to investigate and analyze epstemolegy knowlege study methodology in the teaching of geography as a school subject in Namialo Secondary School. The study involved 36 people, among them 30 students, 5 teachers and 1deputy-director. According to bibliographical study and teacher's experience, it is confident to consider that the theoretical learning and practical learning (real life) felt in the field study have to been seen as a unique methodology in the teaching of geography.

\footnotetext{
${ }^{1}$ Mestre em Ensino de Geografia pela Universidade Rovuma, Nampula / Moçambique; Professor de Geografia na Escola Secundária de Namialo; joaontumua@gmail.com

${ }^{2}$ Doutor em Geografia pelo IESA/UFG, Goiânia / Brasil; Professor Auxiliar da Faculdade de Geociências, Universidade Rovuma, Nampula / Moçambique; eduardobata1983@gmail.com

${ }^{3}$ Doutor em Geografia pelo IESA/ UFG, Goiânia / Brasil; Professor do Mestrado em Geografia, Universidade Estadual de Goiás, Cidade de Goiás / Brasil; profvandervilson@gmail.com
} 
Therefore, this study concludes that any school subject employs different teaching methodology in order to provide students knowledge and experience about the world which surround them. So, the field study is an important methodology in the teaching of geography because it encourages students to develop skills, attitude and scientific willing at their school.

Keywords: Field study; Geography teaching; Teaching and Learning.

\section{Introdução}

Nos últimos anos, a educação em Moçambique tem estado no centro de debates em todos os níveis da sociedade, uma vez que é visto como fator essencial para o desenvolvimento do País. Com efeito, as mudanças políticas, sociais, econômicas em curso, desde o advento da primeira República, em 1975, até a introdução do Sistema Nacional de Educação (SNE), em 1983, impõem desafios acrescidos para a educação e, sobretudo para os principais intervenientes, nomeadamente: professores, alunos e a sociedade como um todo. A geografia, ciência que estuda as contradições que se operam no espaço social/geográfico não está isenta dessas mudanças. Daí que exige-se um repensar das formas e dos meios, ou seja, suas metodologias de ensino, não só pelo fato de ser uma disciplina de aquisição de conhecimento, mas também porque seus conteúdos constituem ferramentas para a construção da cidadania.

Assim como em outros domínios do saber científico, na geografia, o trabalho de campo possui um enorme valor no processo de ensino e aprendizagem, já que permite, dentre outros aspectos, a construção de habilidades, atitudes e valores, assim como o elo entre a teoria e a prática no ambiente escolar, base para o ensino da geografia.

Apesar das vantagens elencadas, o potencial intríseco à geografia tem sido pouco ou quase inaproveitado pelos professores no ensino da disciplina, tanto em nível do $1^{\mathrm{o}}$ ciclo $\left(8^{\mathrm{a}}\right.$ a $10^{\mathrm{a}}$ classes) quanto no nível do $2^{\circ}$ ciclo $\left(11^{\mathrm{a}}\right.$ a $12^{\mathrm{a}}$ classes $)$ do ensino secundário geral. Por exemplo, na Escola Secundária de Namialo, local de trabalho e da pesquisa, no período entre 2015 e 2019, em nível das $8^{\mathrm{a}}$ e $11^{\mathrm{a}}$ classes, foram realizadas somente 3 aulas de campo. Dessas uma (1) em 2015, e duas (2) em 2016 e 2017, respectivamente; número insignificante, considerando as potencialidades do Posto Administrativo de Namialo (PAN), tanto do ponto de vista físico (rios, relevo, vegetação) quanto socioeconômico (indústrias, transportes, energia, etc.).

Portanto, no contexto da Escola Secundária de Namialo e não só, são várias as dificuldades apontadas pelos professores, tanto no ensino da geografia, quanto em outras disciplinas escolares e, como consequência disso, muitos alunos sentem-se desmotivados no e pelo ambiente educacional. Nesse contexto, cabe ao professor transformar essa realidade que tanto obsta o processo de ensino e aprendizagem, através da adoção de metodologias alternativas, ou seja, estratégias didáticas atraentes e atrativas para o aluno. Dentre outros métodos, o professor pode recorrer ao trabalho de campo. Porém, é importante destacar que, por ser um método didático que auxilia o professor em suas aulas teóricas, não deve ser utilizado sem preparação prévia, tendo em vista que sua função primordial é a materialização da teoria. Nisso, concordamos com Alentejano e Rocha-Leão (2006, p.51) quando afirmam que "trabalho de campo é fundamental, mas, se realizado desarticulado do método e da teoria, torna-se banal"

Não tanto na lógica de banalização, mas como resultado da desvalorização do trabalho de campo, as informações obtidas durante a pesquisa de campo demostram que os professores que lecionam a disciplina de geografia na Escola Secundária de Namialo poucas vezes realizam 
estudos de campo. Concorrem para isso, as dificuldades financeiras da parte dos alunos para suportar o custo das aulas de campo aliado a alegada falta de tempo para realizar este tipo de atividades e, sobretudo a falta de domínio das principais áreas para as aulas de campo.

Tais pretextos não justificam, no nosso entender, a ausência ou a baixa frequência de realização das aulas de campo, pois Namialo dispõe de um mosaíco paisagístico deslumbrante com "condimentos" suficientes para a realização de aulas de campo. Portanto, não precisa "grandes" orçamentos para suportar este tipo de atividades já que locais próximos como o Rio Monapo, a pedreira, podem ser alcançados a pé, ou seja, sem demandar o uso de qualquer meio de transporte.

Considerando os aspectos elencados, buscamos, nesse artigo, analisar as práticas de aula de campo, enquanto estratégia metodológica no ensino de geografia na Escola Secundária de Namialo, partindo da experiência de campo realizada com os alunos da $11^{\mathrm{a}}$ classe. Para tanto, foi realizado o trabalho de campo no período entre março a agosto de 2019, na Escola Secundária de Namialo, bem como no Posto Adminitrativo de Namialo, com intuito de produzir informações importantes à compreensão da realidade em estudo. A pesquisa envolveu 36 pessoas, das quais 30 alunos, 5 professores e 1 Diretor Adjunto Pedagógico, da Escola Secundária de Namialo.

E para permitir a construção de um corpo teórico capaz de captar os diversos entendimentos sobre o trabalho de campo, sobretudo a sua importância no ensino, realizou-se a pesquisa bibliográfica e documental, consubstanciada à experiência acumulada ao longo de uma década de trabalho docente na Escola Secundária de Namialo. A partir dos dados da pesquisa bibliográfica e do trabalho de campo é possível dizer que o ensino de qualquer disciplina escolar está diretamente associado à utilização de metodologias, isto é, caminhos que ajudem aos alunos a adquirirem experiências e conhecimentos do mundo no qual vivem. A aula de campo, por sua vez, constitui junto a outros recursos metodológicos, uma estratégia metodológica útil à teoria e prática do ensino da geografia, mas não como duas partes opostas, as quais se busca reconciliar e, sim como elementos indissociáveis numa abordagem dialética.

A esse respeito, Tricart (2017), um dos teóricos da abordagem sistêmica, lembra que é falso opor uma geografia teórica e outra que seria a ciência do concreto. Com efeito, teoria e observação são indissociáveis. Os fatos que estudamos existem independentemente de nossas disciplinas e, geralmente, antes que elas se organizem. Nesse sentido, aula de campo permite o reconhecimento do que existe a prior do contacto com ele, possibilita, outrossim, a construção de habilidades, atitudes e valores, assim como a articulação entre a teoria e a prática no ambiente escolar.

Visando a sistematização das ideias contidas no texto, dividimos o artigo em quatro partes interdependentes. Nessa lógica, a primeira traz as contribuições, de cunho teórico, ou seja, os avanços da ciência geográfica, a partir da leitura de diversos autores dos quais, Langa (2017); Caracristi e Fonseca (2011); Cavalcanti (2010); Nascimento (2004), Straforini (2004) e outros, baseado em diferentes correntes da geografia, bem como aquela que aborda a Geografia e o ensino no contexto escolar, sobretudo em Moçambique. Ainda, nessa parte, é feito um breve resgate sobre o processo da constituição da Geografia como ciência social, assim como os desafios da Geografia Escolar no século XXI.

$\mathrm{Na}$ segunda parte, buscamos ressaltar a importância da aula de campo no ensino da geografia, como uma atividade que estimula a aprendizagem, e como essa proposta pode influenciar positivamente o desenvolvimento do aluno/cidadão. Apresentamos, de seguida - na terceira parte, as percepções dos professores e dos alunos da Escola Secundária de Namialo, considerando as suas experiências, em relação à aula de campo. Para encerrar o texto, 
destacamos, em jeito de considerações finais, os principais achados da pesquisa, ciente das suas limitações, bem como da complexidade da temática trabalho de campo, considerando que o advento da sistematização da geografia como ciência muito se deve ao conjunto de pequisas e relatórios de campo escritos por viajantes, naturalistas e aventureiros ao serviço de sociedades e impérios, tal como assinalam Alentejano e Rocha-Leão (2006).

\section{A Geografia escolar e a prática do ensino de Geografia em Moçambique}

A Geografia, como ciência social e disciplina escolar vem passando, nas últimas décadas, por diversas transformações. O contexto sócio - histórico contemporâneo dos últimos anos são radicalmente diversos daquele em que a ciência geográfica emergiu no âmbito das ciências modernas. (CARACRISTI e FONSECA, 2011). Atualmente, a Geografia passa por um período de intenso debate sobre as diferentes correntes do pensamento envolvidas com a sua produção científica, assim como o conjunto de questões as quais a geografia deve responder.

Desde o seu "nascimento" como ciência, a Geografia sofreu inúmeras transformações, precisando constantemente readequar-se, a fim de atender as mudanças ocorridas durante esse processo. Os primeiros conhecimentos da ciência geográfica foram obtidos e sistematizados pelos gregos. Cavalcanti e Viadana (2008) afirmam que foram os filósofos gregos que viveram entre os séculos VII e VI a. C. a buscar uma explicação do mundo em termos físicos, deixando de lado a explicação dos fenômenos naturais a partir dos mitos, e procuraram explicações da necessidade da sociedade da época por meio da razão. Desse modo,

a história da Geografia está implicitamente associada à história da humanidade, às suas relações com a natureza, à sua evolução. O "instinto geográfico", ou seja, o sentido de orientação, de localização e de mobilidade no espaço terrestre não integra somente a natureza humana, já que os animais também o possuem em graus diversos. No homem, todavia, esse sentido é trabalhado na razão, para atender, sejam as necessidades elementares de sobrevivência, sejam as necessidades secundárias ou artificiais. A Geografia, como produção intelectual, como teoria, conhecimento sistematizado e registado (inclusive sua denominação), surgiu na Grécia Antiga, tendo como motivação básica o comércio através dos mares (NASCIMENTO, 2004, p. 25).

A ciência geográfica registrou sua estagnação na Idade Média, considera época das trevas. Este fato foi motivado pelos seguintes fatores: (i) as guerras de invasão bárbara que influnciaram toda a Europa, (ii) a destruição dos sistemas de comunicações e a Igreja passou a representar o maior poder em nível da Europa e, em função disso, todas as questões da época passaram a ser interpretadas com base na bíblia. Nessa época o Homem passa a não fazer viagens de descobrimentos, difunde-se o cristianismo e os problemas de ordem religiosa ganham centralidade, em detrimento da ciência.

Foi na época renascentista, Séculos XIV a XVII, que a ciência geográfica retomou o seu desenvolvimento, influenciado em grande medida pelo desenvolvimento da Europa induzido pelo florescimento do comércio no Mediterrâneo, cujas marcas são nascimento de importantes cidades como Florença, Geneva, Roma. Para Copatti (2017), o Renascimento e a crença da razão, ampliou a busca pela compreensão do mundo por meio da racionalidade, que constituía a preocupação de vários campos de saber como a filosofia e especialmente, a Geografia. Foster e 
EM

pág. 149-178

Kant (s/d) marcaram esse período e as bases da ciência moderna, através de observações, descrições, análise e comparações de dados de determinados recortes espaciais. Foster desenvolveu conhecimentos teórico-metodológicos e Kant destacou-se significativamente na compreensão epistemológica da Geografia. (MOREIRA, 2012).

Embora os primeiros conhecimentos geográficos tenham sido obtidos e sistematizados na Antiguidade clássica, foi no século XVIII, no entanto, que a Geografia é reconhecida como ciência autônoma, a partir da sistematização dos conhecimentos o que contribuiu, significativamente, para a constituição das bases teóricas e metodológicas dessa ciência.

Para Andrade (2008), o desenvolvimento das ciências em geral e da Geografia particularmente, acelerou-se nos séculos XVIII e XIX, em consequência da expansão do capitalismo. O capitalismo comercial provocaria, a partir do século XV, grande expansão das navegações e, como fruto disso, o descobrimento de novos continentes e ilhas, fazendo com que se intensificasse o comércio entre os povos que viviam em condições naturais, e em organizações sociais das mais diversas.

A institucionalização da Geografia escolar teve seu marco ainda no século XIX, sendo mais aprofundada no século XX. O surgimento da Geografia escolar é parte da institucionalização da ciência geográfica, tendo-se iniciado, naquela época, em países desenvolvidos. Nesse contexto, o ensino de Geografia possuía bases positivistas, numa perspectiva tradicional, caracterizando-se pelo foco no professor, que era considerado detentor de conhecimentos não questionáveis. (COPATTI, 2017).

Nesse período, a geografia em Moçambique baseava-se no conhecimento autóctone, ou seja, nas experiências do quotidiano. As comunidades locais eram obrigados a aprender de acordo com as vontades e/ou necessidades do colonizador. Essa lógica perdorou até aos primeiros anos da independência política, mais ou menos até 1983 quando foi introduzido o SNE.

A integração da Geografia como disciplina escolar resultou das reivindicações do seu estatuto de disciplina escolar do qual alcança num momento em que as preocupações no mundo apresentam significados espaciais, dentro de um espaço de produção, organização e controle social, desempenhando um papel importante no processo de ensino e aprendizagem.

Em Moçambique, apesar da persistência de lacunas nos escritos sobre a introdução da Geografia como disciplina escolar, admite-se que ela tenha acompanhado o sistema educativo moçambicano que teve seu marco inicial no período colonial. De fato, analisando

o sistema educacional colonial, onde a aprendizagem foi caracterizada por um ensino altamente racista e seletivo para a população negra, a matéria de ensino de Geografia era fortemente dominada pelos aspectos referentes à metrópole, na sua qualidade de eixo central do estudo geográfico, onde a realidade mais próxima do aluno no estudo geográfico [não era considerada]. (OMAR, 2010, p. 45).

Em linha com Omar (2010), Bata (2018) explica que ainda sob o domínio colonial, nesse período, a pesquisa e o ensino de geografia eram mínimos e voltados notadamente para responder aos objetivos imperialistas da metrópole. Na verdade, a história da Geografia como disciplina escolar em Moçambique tem início no século XX, quando foi introduzida nas escolas com o objetivo de contribuir para a formação dos cidadãos, a partir da difusão da ideologia portuguesa. Com efeito,1969 constitui um marco importante na história da Geografia em Moçambique, pois nesse ano, por força do Decreto - Lei n.49.072, de 20 de junho foi aberto o primeiro curso de 
EM

Bacharelado em Geografia, um ano após a criação da Universidade de Lourenço Marques, atual Universidade Eduardo Mondlane (UEM). Esse curso foi ministrado na Faculdade de Letras da Universidade de Lourenço Marques e teve apoio direto da Universidade de Lisboa, a qual teve papel de tutora, na organização e desenvolvimento do curso. (LANGA, 2017).

Segundo Araújo (1999) citado por Langa (2017), foi da Universidade de Lisboa que vieram as duas primeiras docentes do referido curso, designadamente: Maria Eugênia Correia e Celeste Coelho. Além de que foi nessa Universidade que alguns dos estudantes do primeiro curso de bacharelado em Moçambique terminaram a Licenciatura em Geografia, com ênfase para o Professor Manuel de Araújo, que concluiu a sua Licenciatura em 1974, tornando-se, desse modo, o primeiro geógrafo moçambicano.

$\mathrm{Na}$ atualidade há a necessidade de se pensar uma Geografia que auxilie a compreensão do mundo e de suas transformações, aliás é nisso que a geografia e os geógrafos, por conseguinte, devem ocupar-se e despender suas energias. A Geografia Escolar, por sua vez, tem um papel importante por atuar na conscientização dos alunos, a partir do respeito e da cooperação, vislumbrando relações conscientes no espaço ocupado e com as diversidades nele existentes.

Para Straforini (2004), o ensino de Geografia é fundamental para que as novas gerações possam acompanhar e compreender as transformações do mundo, dando à disciplina geográfica um status que antes não possuía. Desse modo, no contexto escolar contemporâneo, a ciência geográfica precisa dar conta de um emaranhado de conhecimentos, além das mudanças contemporâneas nas relações sociedade-espaço, as quais demandam profissionais capacitados e engajados no efetivo processo de ensino e aprendizagem.

Assim, pensar tais necessidades demanda uma reflexão sobre o papel da Geografia na compreensão da diversidade social, cultural, econômica, políticas e naturais, exigindo constante reconstrução-readaptação dos profissionais, visto que, a dinâmica social altera-se rápida e intensamente, o que requer a utilização de diferentes recursos educativos que abarquem a complexidade de temas que envolvem o ensino da Geografia Escolar. Nesse sentido, o conhecimento das teorias referentes à prática educativa e sobre métodos e recursos didáticos adequados para a aprendizagem são fundamentais no exercício da docência.

Frente aos desafios de ordem teórico-metodológicos, a Geografia em Moçambique se vê com uma forte ligação à ideologia política do país. Se antes, isto é, no período colonial, se fez uma Geografia com intuito de desenvolver o projeto colonial, do qual a Geografia Regional foi fundamental para o conhecimento do território e, assim subjugar os povos e despojá-los de seus territórios e recursos, com a independência, a Geografia assume outros objetivos, todavia, não se desprende da sua relação com o poder político e do governo, mas agora preocupado em conhecer o território para desenvolver o projeto da unidade nacional, dando bases para a Nova Nação. (LANGA, 2017).

De fato, à data da Independência nacional, Moçambique herdou uma ciência geográfica e um ensino de geografia profundamente marcado pelos interesses do poder colonial, o que exigia à jovem nação uma mudança radical na sua concepção e metodologia. É nesse contexto que, o processo educativo em Moçambique registra significativas mudanças, na sua estrutura curricular e metodológica, implementando-se, assim, a atual geografia "renovada", em que o professor e os alunos são parte integrante do processo de ensino e aprendizagem. Portanto, uma geografia que valoriza a participação dos alunos, assim como o pensamento crítico sobre diferentes fenômenos geográficos. 
EM

QUESTÃO

V.13 N. $03 \bullet 2020$

pág. $149-178$

\section{A organização da atividade de campo}

Antes de descrevermos a forma como decorreu a atividade de campo que, nesse caso serviu de experiência na organização e condução de uma aula de campo, vale a pena assinalar que para a produção de informações usou-se o questionário, dirigido aos alunos da $11^{\mathrm{a}}$ classe, a entrevista semiestruturada aplicada aos cinco professores de geografia e um diretor adjunto pedagógico, além da técnica da observação que permitiu visualizar as contradições que se operam no espaço, tendo em vista o embasamento teórico da pesquisa.

Para tal foram organizadas 04 aulas de campo envolvendo alunos de quatro turmas da $11^{\mathrm{a}}$ classe. E visando facilitar o controle/gestão dos alunoas, bem como a maximização da atividade, foram criados dois grupos, sendo que cada um desses grupos teve duas aulas. No final de cada aula, as atividades realizadas foram objeto de análise e/ou avaliação, tanto pelos alunos quanto pelos professores de Geografia.

\section{Observação}

A observação foi fundamental para a pesquisa, pois foi com base nela que observamos as diiferentes paisagens em Namialo com o intuito compreender, mas sobretudo questionar o arranjo espacial, bem como as contradições que decorrem desse processo, tendo em conta as peculiaridades da Vila sede de Namialo. Com efeito, fomos observar in loco, grande parte dos aspectos discutidos em sala de aula (relevo, hidrografia, indústrias, entre outros), assim como a visualização das formas de organização do espaço e da paisagem envolvente da Escola Secundária de Namialo.

\section{Entrevistas}

Sendo a entrevista uma técnica relevante na abordagem qualitativa, optamos pela entrevista semiestruturada, pois consideramos portadora de maior coerência relativamente aos objectivos que definimos para este trabalho, além de que permite ao entrevistado ter liberdade para desenvolver as respostas segundo a direcção que considere adequada, explorando, de uma forma reflexível e aprofundada, os aspectos que considere mais relevantes. Nesse contexto, a entrevista permitiu obter diferentes precepções dos entrevistados sobre a contribuição das aulas de campo no ensino de geografia.

Assim foram entrevistados um conjunto de atores do processo de ensino e aprendizagem, os quais consideramos serem portadores de conhecimentos profundos sobre o assunto, das quais destacamos quatro professores da disciplina de geografia. Foi entrevistado, também um membro de direcção, isto é, o Director Adjunto Pedagógico do $2^{\circ}$ Ciclo. Com este último entrevistado, interessava-nos compreender dele, como são organizadas as aulas de campo e, sobretudo que dificuldades são persistem na realização dessas atividades.

\section{Questionários}

A opção pelo questionário, enquanto instrumento de coleta de dados, visou colocar aos inqueridos, neste caso os alunos das quatro turmas da $11^{\text {a }}$ classe, uma série de perguntas relativa à sua situação social e, sobretudo suas opiniões/nível de conhecimento sobre aula de campo no ensino de geografia. Foram selecionados, intencionalmente, 30 alunos, nas quatro turmas das $11^{\mathrm{a}}$ 
classe, sendo que a cada um deles foi aplicado um questionário semiestruturado cujo objetivo era avaliar os seus conhecimentos em relação ao trabalho de campo, bem como os conhecimentos específicos sobre a ciência geográfica.

\section{A escola secundária de Namialo: o locus da pesquisa}

A Escola Secundária de Namialo (figuras 1 e 2) é bastante privilegiada do ponto de vista do seu potencial, o que pode permitir a realização de muitas aulas de campo. Isso porque os principais aspectos físico-geográficos estão relacionados aos recursos hídricos (a Escola localizase próximo do Rio Monapo), a estrutura geológica envolvente é constituída por rochas magmáticas (montanhas) e sedimentares, a vegetação é diversificada (galeria, arbustiva e exótica).

Portanto, tendo em conta o potencial o Posto Administrativo de Namialo, no qual se insere a Escola Secundária de Namialo, buscamos com efeito, compreender a percepção dos alunos e dos professores sobre as metodologias de ensino de Geografia. Para tanto, foram questionados os alunos sobre o objeto de estudo da geografia; os métodos de ensino usados no ensino de Geografia e, sobretudo a importância do estudo da Geografia. Todos esses aspectos serviram para, finalmente, chegar-se ao local de partida de aula de campo na Escola Secundária de Namialo. É preciso dizer que esta pergunta permitia múltiplas respostas, o que espelha também diferentes percepções sobre o objeto de estudo da geografia. Não que a geografia tenha distintos objetos de estudo, mas porque no contexto do ensino dessa disciplina ainda persistem confusões sobre o espaço, transformado, em transformação e com o poder de moldar a vida do homem.

Figura 1 - Localização geográfica da Escola Secundária de Namialo.
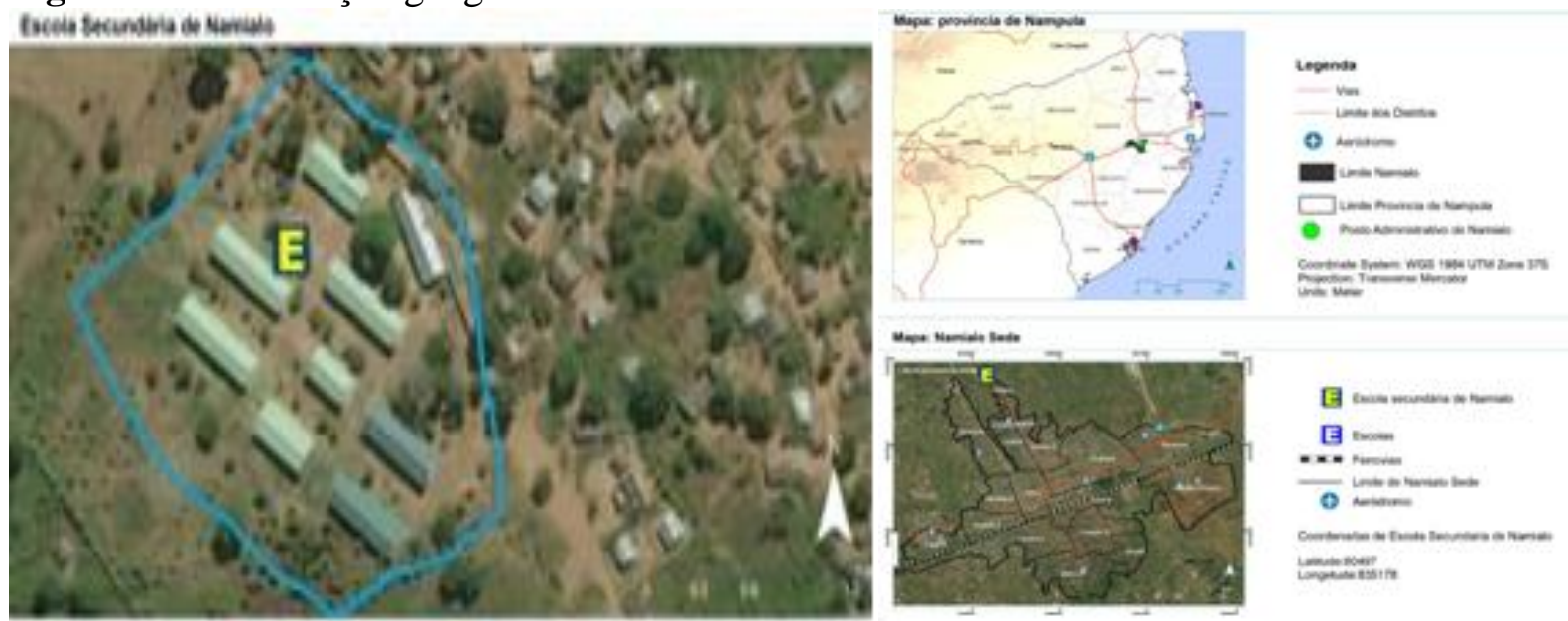

Fonte: ISAC (2018). 
EM

QUESTÃO

V.13 N. $03 \bullet 2020$

pág. $149-178$

Figura 2 - Vista parcial do bloco principal da Escola Secundária de Namialo.

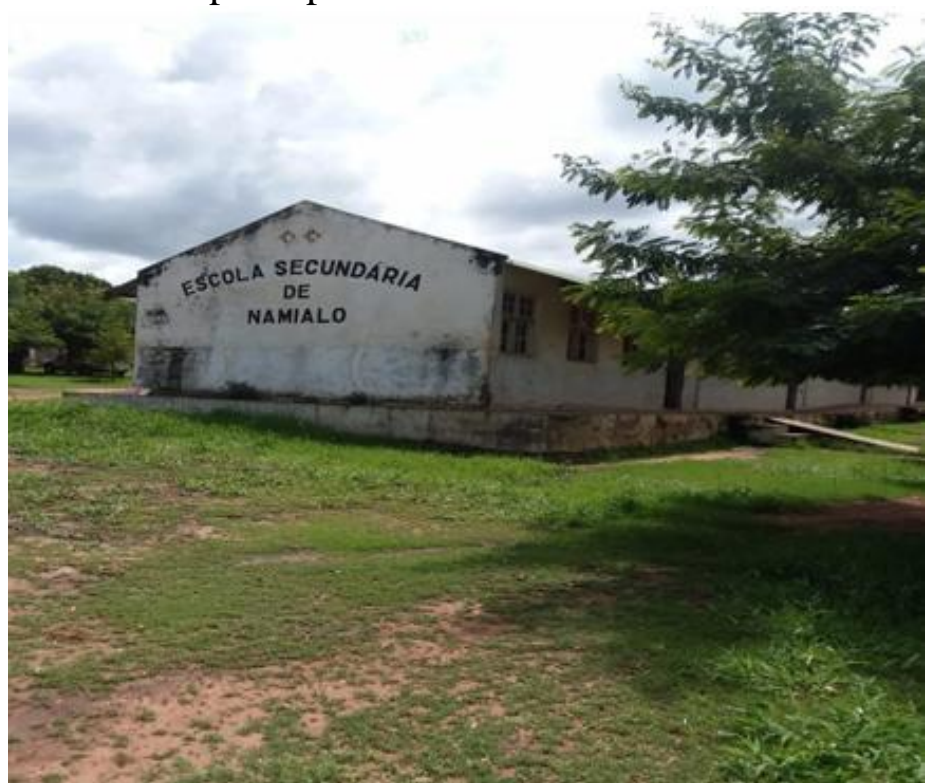

Fonte: Trabalho de campo em Namialo, agosto de 2019. Autoria: João Ntumua, 2019.

\section{Aula de campo como prática de ensino e aprendizagem: sua contribuição no ensino de Geografia}

Em relação ao objeto de estudo da Geografia, os alunos apresentaram opções diferentes. De fato, dos 30 alunos inqueridos, 23 destacaram que a Geografia tem como objeto de estudo "espaço geográfico" (77\%); 6 destacaram a opção "superfície terrestre" (20\%) e apenas 1 destacou "aspectos físicos geográficos e socioeconômicos", que corresponde a 3\%, respectivamente, conforme é apresentado na figura 3.

Figura 3 - Percepção dos alunos sobre objeto de estudo de Geografia.

\begin{tabular}{|c|c|c|}
\hline \multicolumn{3}{|c|}{ Qual é o objeto de estudo da Geografia? } \\
\hline $77 \%$ & & \\
\hline & & \\
\hline & & \\
\hline & & \\
\hline & $20 \%$ & \\
\hline & D & 30 \\
\hline Espaço geográfic & Superfície terrestre & $\begin{array}{l}\text { Aspectos físicos geográficos e } \\
\text { sócio económicos }\end{array}$ \\
\hline
\end{tabular}

Fonte: Trabalho de campo, agosto de 2019. Organização: João Ntumua, 2019. 
EM

pág. 149-178

A divergência das acepções dos alunos em relação ao objeto de estudo da Geografia pode resultar da discussão e interpretação dos professores e da bibliografia existente, que versam sobre o assunto. É verdade que parcela significativa dos alunos compreendem o espaço geográfico como objeto de estudo dessa ciência, contudo, alguns considerem a superfície terrestre como objeto de estudo da ciência geográfica, na qual encontramos os aspectos físicos geográficos e socioeconômicos.

A discussão sobre a delimitação do objeto de estudo da Geografia vem sendo desenvolvida desde o surgimento da Geografia como ciência. Para Santos (1986), o problema da ciência está na definição do objeto de cada disciplina no universo do saber. No caso da Geografia, gerou o mais grave dos erros no exercício teórico metodológico: a confusão, entre a ciência propriamente dita e o seu objeto. Para o autor, o que se quer conhecer, pelo intermédio das ciências particulares, são os diversos aspectos da realidade em seu aspecto global.

Santos (op.cit.,) considera que o objeto de estudo da geografia é o espaço geográfico, no qual há interacção entre Sociedade e Espaço. O autor assinala, finalmente, que:

o espaço deve ser considerado como um conjunto de relações realizadas através de funções e de forma que se apresentam como testemunho de uma história escrita por processos do passado e do presente. Isto é, o espaço se define como um conjunto de formas representativas de relações sociais do passado e do presente e por uma estrutura representada por relações sociais que estão acontecendo diante dos olhos e que se manifestam através de processos e funções. O espaço é, então, um verdadeiro campo de forças cuja aceleração é desigual. Daí porque a evolução espacial não se faz de forma idêntica em todos os lugares (SANTOS, 1986, p. 122).

Ainda problematizando o objeto de estudo da Geografia, enquanto área do conhecimento, Lefebvre (2006) considera objeto da geografia o espaço social, ou seja, o espaço construído pelo homem. Para o autor,

a estrutura do espaço organizado não é uma estrutura autónoma com suas próprias leis de funcionamento e transformação, tampouco uma mera expressão da estrutura de classes emergindo das relações de produção. Ela é um componente, dialeticamente definido, das relações gerais de produção, que são simultaneamente sociais e espaciais. Entretanto, as relações (espaciais) de produção não são dissociadas das relações (sociais de produção), mas sim dialeticamente inseparáveis, num materialismo histórico-geográfico (LEFEBVRE, 2006, p. 34).

O entendimento sobre o objeto de estudo da geografia apresentado por Lefebvre (2006) dialoga com o que foi proposto por Santos (1986), pois ambos consideram a relação sociedade e espaço como elementos integrantes do espaço geográfico, ou seja, espaço socialmente construído pelo homem.

Ainda sobre objeto da geografia, perguntamos aos professores que leccionam a geografia na Escola Secundária de Namialo. A divergência na denominação do objeto de estudo nos alunos persiste também entre os professores. Conforme o depoimento de dois professores é notável essa divergência, pois para o $\mathrm{P} 2$, 
o objeto de estudo de Geografia é o espaço geográfico, mas ao nível em que leciono, sobretudo a $8^{\mathrm{a}}$ classe recomendamos que alunos compreendam a superfície terrestre como objeto da Geografia, porque isso depende da interpretação cognitiva e desenvolvimento de aprendizagem dos alunos. Nos nossos livros didácticos também aparece à superfície terrestre como objeto de estudo da Geografia (P2, entrevista, agosto de 2019).

Já para o P5,

a Geografia estuda a Terra, ela busca compreender as relações existentes entre os aspectos físicos geográficos e socioeconômicos, suas interacções. Atualmente o objeto de estudo da geografia é cada vez discutido, nós os professores transmitimos os alunos de acordo com os manuais e as classes que lecionamos (P5, entrevista, agosto de 2019).

Esses posicionamentos demostram a divergência de conhecimento transmitido aos alunos no ensino secundário. Portanto, admitirmos que os alunos da $8^{\mathrm{a}}$ classe devem compreender a superfície terrestre como objeto de estudo da Geografia para mais tarde, isto é, a partir da $11^{\text {a }}$ classe, lhes apresentar o espaço geográfico como sendo objeto da Geografia consideramos ser algo muito complicado.

Nosso entendimento é de que os alunos deveriam ser ensinados desde a $8^{\mathrm{a}}$ classe que o objeto de estudo da Geografia é o espaço geográfico e, gradualmente irem fortalecendo a ideia ao longo de seu percurso de aprendizagem, sobretudo na $10^{\mathrm{a}}, 11^{\mathrm{a}}$ e $12^{\mathrm{a}}$ classes, até ao nível superior, para aqueles que optarem pela geografia como curso superior.

Como dito, a concepção do objeto de estudo da Geografia como espaço geográfico permite problematizar o conhecimento da importância da realidade vivida pelo aluno no seu quotidiano, a interpretação dos fatos e fenômenos da vida, bem como as relações estabelecidas entre o homem e os demais aspectos sociais da vida. Na verdade, conforme Callai (1998), a geografia busca a formação do cidadão com consciência do espaço das coisas, dos fenômenos que ele vivencia ou não, definir o espaço ocupado por nós e pelas coisas na prática saindo da teoria, é entender que nós vivemos no espaço, que tudo que existe ocupa um lugar no espaço.

Sendo o espaço geográfico o objeto estudo da Geografia, então é importante, tanto para os alunos, assim como para os professores. Cada espaço contribui para o conhecimento do aluno, para isso é necessário que esse educando esteja atento ao que está em seu redor, o que a Geografia deve ensinar a ele.

Com feito, quando questionamos aos alunos sobre a importância da Geografia no seu quotidiano, dos 30 alunos inquiridos, 21 alunos escolheram a opção - permite a construção da cidadania (70\%), 7 disseram que - permite compreender as interacções e relações que se estabelecem no espaço (23\%), os restantes $2 \%$ escolheram a opção - permite o conhecimento da sistematização geográfica do espaço mundial (7\%), conforme é apresentado na figura 4.

A respeito da importância da Geografia como disciplina escolar, para os alunos, constatamos que na sua maioria (70\%), enxergam na como a disciplina responsável por estudar o espaço de maneira geral, condição e caminho do projeto da construção da cidadania; das relações estabelecidas na sociedade e o conhecimento de vários lugares no mundo. 
EM

QUESTÃO

V.13 N. $03 \bullet 2020$

pág. $149-178$

Figura 4 - Percepção dos alunos sobre a importância de estudo da Geografia.

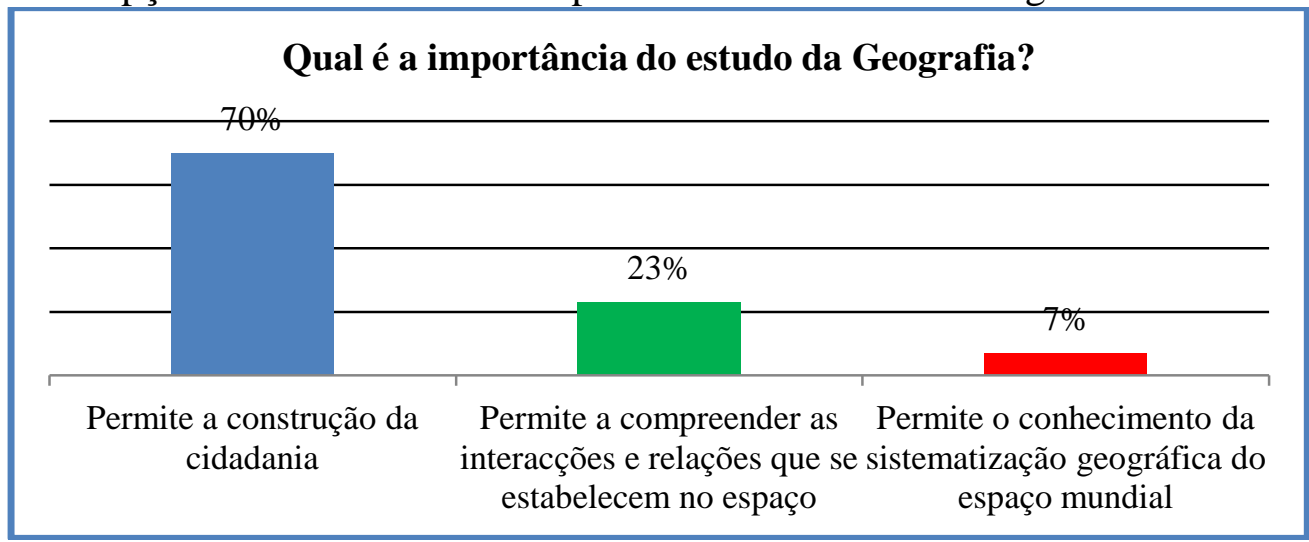

Fonte: Trabalho de campo, agosto de 2019. Organização: João Ntumua, 2019.

Para os professores, a geografia também se vincula ao projeto de cidadania, tal como disse o P1 que a geografia "preocupa-se em formar cidadãos com consciência, participativos e críticos; ela trabalha com os conteúdos considerados essenciais e também com os transversais que estão nos planos curriculares para serem trabalhados, juntos com os demais conteúdos".

O P3, por sua vez, lembra que a Geografia transmite aos alunos o caráter didático e de experiência vivida todos os dias, nas práticas de vida dos alunos, daí que " ela é importante por ajudá-los a entender fatos do dia-a-dia, entre os quais o desemprego, a violência, a falta de habitações, desigualdades sociais e problemas ambientais".

Da assertiva dos professores, entendemos que eles vão além daquele conceito pronto da Geografia como o estudo do espaço e problematizam-no, identificam nas entrelinhas desse conceito questões que eles conhecem de perto, que estão presenciando ou até mesmo vivenciando. Destarte, é essa Geografia que propomos; que ajuda a entender as questões do quotidiano, auxiliando com a reflexão e crítica no meio em que vivemos, fortalecendo por via disso, o conceito, assim como o papel da geografia no desvelamento das máscaras sociais, conforme proposto por Ruy Moreira.

Nesse sentido, Lima e Vlach (2002) são enfáticos sobre o papel da Geografia e entendem que ela permite conhecer o espaço geográfico e o funcionamento da natureza em suas múltiplas reações, de modo a compreender o papel das sociedades em sua construção e na produção do território, da paisagem e do lugar; identificar e avaliar as ações dos homens em sociedade e suas consequências em diferentes espaços e tempos, de modo a construir referenciais que possibilitem uma participação propositiva e reativa nas questões socioambientais locais.

Atualmente, o ensino da Geografia tem tido relevância e interesse para a compreensão do processo de organização do espaço, e funciona na prática como um processo de ensino e de comunicação assumindo desse modo, um papel primordial na divulgação da ciência geográfica pelo docente e na sua apropriação por parte dos alunos.

Assim, compreende-se que o ensino da Geografia deve propiciar a observação, percepção, análise e compreensão do espaço geográfico enquanto espaço da ação humana em interação com a natureza. Por essa razão, os professores têm de manter um diálogo permanente com o passado, o presente e o futuro para melhor conhecer sua própria ciência e saber constituir projetos (inter) disciplinares na escola. Os professores, esses precisam ainda ter clareza dos aspectos teóricometodológicos da ciência geográfica, pois tal compreensão lhes possibilitará definir os objetivos, 
bem como seleccionar os conteúdos a ensinar, estando desse modo preparado para trabalhar no espaço da sala de aula ou fora dela. (CALLAI, 1998).

Portanto, no intuíto de conhecer a metodologia utilizada pelos professores no ensino de Geografia colocamos a seguinte questão: Que metodologias de ensino têm utilizado na sua prática docente? Os professores foram unânimes em afirmar que, atualmente, é comum a adoção da abordagem tradicional, pautada na utilização do método expositivo e da transmissão de conteúdos, pelo professor - da herança positivista. Aliado a esses métodos os professores referiram que a elaboração conjunta sempre é exigida pelos planos curriculares e, no caso da Geografia, os professores procuram sempre que possível transmitir conteúdos baseando-se no princípio da realidade mais próxima do aluno, como forma de explorar as potencialidades do meio no qual se insere a escola.

Durante a observação/assistência às aulas, uma das práticas recorrentes nos grupos de disciplina e recomendado nas diretrizes curriculares em Moçambique, constatamos que parte considerável dos professores limita-se ao uso de livros didáticos para a transmissão de conteúdos. Lima e Vlach (2002, p. 45), advertem que,

o ensino de Geografia, construído pela reprodução de manuais, conduz a uma insatisfação e a um descomprometimento dos alunos frente a essa disciplina, podendo se perceber afirmações que reforçam a ideia de que a metodologia utilizada pela maioria dos professores nas escolas da cidade não tem relação com a vida quotidiana dos alunos, o que direcciona a aprendizagem para repetições, impossibilitando a criação/recriação.

Por esse motivo, a adoção de meios de ensino bem selecionados e utilizados de forma adequada pelo professor em sala de aula melhora, em tese, a qualidade de ensino e aprendizagem, além de propiciar maior participação dos alunos e dinamismo na sala de aula. Na verdade, o ensino de conteúdos, assim como o uso de recursos que vão de encontro à realidade dos alunos no ensino de Geografia despertaria a curiosidade do aluno, estimulando, por conseguinte, a sua participação na sala, assim como a abertura para a discussão, debate, reflexão, pilares para a construção de conhecimento sobre fenômenos e fatos geográficos.

Para que o ensino de Geografia possa integrar os alunos no seu processo de ensino e aprendizagem é necessário que seja selecionado adequadamente a metodologia pelo professor, uma estratégia que visa à formação do aluno, ou seja, a tornar cidadão, considerado sujeito ativo do processo de ensino capaz de conduzi-lo à realidade, de forma a compreender o mundo ao qual está inserido e transformá-lo em um cidadão crítico e consciente, isto é, de consciência crítica.

Existem diversas metodologias de ensino que abrangem distintas abordagens, entre elas: a tradicional ou conteudista, a sócioconstrutivista, a sóciointeracionista, entre outras. Cada uma delas possui um foco de ação. Como dissemos, os professores de Geografia da Escola Secundária de Namialo persistem no uso de métodos tradicionais. Esse fato tem, no nosso entender, implicações negativas no PEA, pois sugere a estagnação do conhecimento geográfico, 0 professor torna-se autoritário, dificultando a interação e, principalmente a participação dos alunos.

Como ficou claro, ao longo das entrevistas realizadas durante o trabalho de campo, os professores nos seus depoimentos não apontam a aula de campo como estratégia metodológica a ser usada por eles. Tal situação pode denotar a falta da prática desta atividade didática pelos professores de Geografia na Escola Secundária de Namialo. 
EM

pág. $149-178$

Tendo em conta a importância da aula de campo no processo de ensino da geografia, uma vez que possibilita o desenvolvimento do saber prático frente às representações espaciais/sociais e teóricas trabalhadas em sala de aula, foram colocadas, durante o trabalho de campo questões relacionadas à aula de campo, tanto aos alunos, assim como aos professores da ES de Namialo.

A partir do questionário aplicado, 20 alunos consideram aula de campo como sendo aquela que se realiza fora da sala de aula (67\%); 6 consideram como sendo aquela que usa a observação como método principal de estudo (20\%) e 4 revelaram não ter conhecimento (13\%), conforme é representado na figura 5.

Figura 5 - Percepção dos alunos sobre aula de campo.

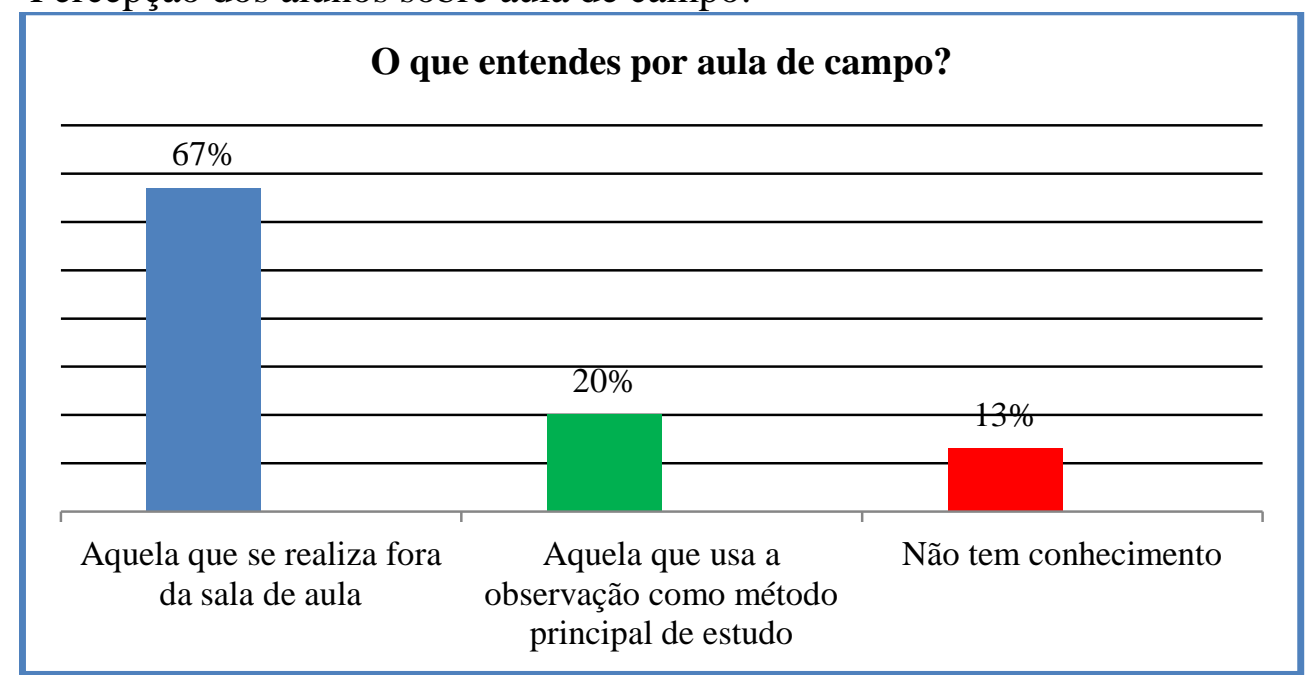

Fonte: Trabalho de campo, agosto de 2019. Organização: João Ntumua, 2019.

$\mathrm{Na}$ figura 5, pode-se observar que a maior parte (67\%) dos alunos considera a aula de campo como atividade pedagógica realizada fora da sala de aula. Esses consideram ainda as aulas de campo como a saída da escola, o deslocamento do ambiente urbano para o campo e a observação da paisagem. Notamos, no entanto, que 4 alunos, não têm e/ou não apresentaram qualquer ideia sobre a importância deste valioso método de ensino e aprendizagem, pois das opções dadas aos alunos não assinalaram em nenhuma delas. Pensamos que a falta de conhecimento sobre a aula de campo pode estar relacionada à fraca realização desta atividade pelos professores na Escola Secundária de Namialo.

Os professores, por sua vez, relacionam a teoria e prática como elementos básicos da aula de campo, daí que a:

aula de campo representa o momento que se articula teoria e a prática, não reduzindo o mundo do conhecimento empírico. É uma metodologia bastante usada em ciências naturais e do ambiente, que consiste na observação de fatos ou fenômenos. É muito importante na disciplina de Geografia, porque o objeto de estudo dessa disciplina permite a observação (P1, entrevista, agosto de 2019).

A aula de campo consiste na observação, experimentação de fatos ou fenômenos que se pretende estudar, visando compreender a teoria para prática. Atualmente é muito usado em várias ciências, assim como em Geografia. Ela ajuda a 
observar, entender os fenômenos através da experiência (P3, entrevista, agosto de 2019).

Aula de campo é ir estudar e observar de perto os assuntos trabalhados em sala de aula, com essa metodologia o aluno se sente parte integrante do processo de ensino e aprendizagem e permite a compreensão de conteúdos abordados em sala de aula (P4, entrevista, agosto de 2019).

No entendimento dos professores, a aula de campo é o meio de transmissão de conteúdos aprendidos em sala de aula, tal posicionamento corrobora com Pinheiro (2013, p. 22) ao afirmar que a aula de campo "constitui uma importante ferramenta metodológica para a mediação entre o aluno e o espaço geográfico”, que garante resultados eficazes na educação geográfica.

Em relação à sua importância, quer dizer o papel da aula de campo questionou-se aos alunos e professores sobre a importância desta para o ensino e aprendizagem da Geografia. Dos 30 inqueridos, 13 alunos afirmaram que a aula de campo permite maior interação com a realidade observada (43\%), 9 destacaram que aula de campo aproxima-nos dos conteúdos aprendidos em sala de aula (30\%) e 8 destacaram que aula de campo facilita a aprendizagem de Geografia (27\%), conforme se representa na figura 6.

Figura 6 - Percepção dos alunos sobre a importância de aula de campo no ensino de Geografia.

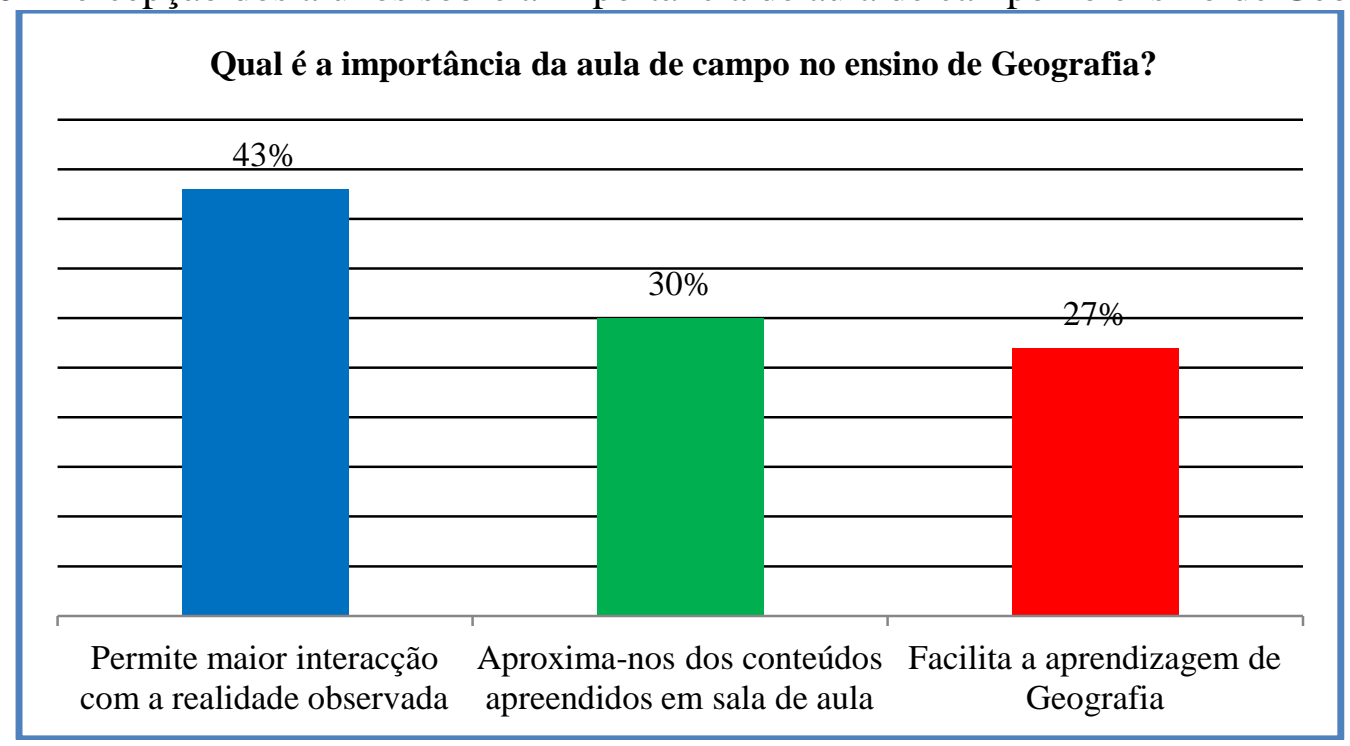

Fonte: Trabalho de campo, agosto de 2019. Organização: João Ntumua, 2019.

Na figura 6, percebe-se que parte significativa dos alunos afirmou que as aulas de campo são importantes para o ensino da Geografia, pois os alunos destacaram que por meio do campo obtêm mais conhecimentos e se sentem instigados a aprender os conteúdos geográficos, daí que há necessidade das aulas práticas para um melhor entendimento do conteúdo teórico ensinado em sala de aula.

Em relação aos professores, esses destacam que a aula de campo é importante porque vai além das evidências da paisagem, do entendimento da sociedade de classes, a relação com homem-meio, assim como articular aos fenômenos relacionados ao processo de construção geográfica. Tal entendimento é ressaltado pelos P2 e P5 ao afirmarem que: 
A aula de campo favorece mais o aprendizado, e é mais atrativa aos alunos, pois constitui um fato que coloca em prática os conteúdos teóricos transmitidos em sala de aula. A maior dificuldade são os procedimentos organizacionais, mas ela constitui uma metodologia estrategicamente excelente no ensino de Geografia (P2, entrevista, agosto de 2019).

Acredito que em uma aula de campo, o educando compreenda melhor o tema abordado, sem contar que sai daquela rotina de sala de aula. Esse tipo de aula os alunos são mais motivados e aprendem com maior facilidade porque observam o que pretendem estudar, ou seja, vivem a realidade do objecto que pretendem analisar (P5, entrevista, agosto de 2019).

De fato, o Director Adjunto Pedagógico ressalta a importância da aula de campo para o ensino, não somente em Geografia, mas também em outras disciplinas. Este considera que aula de campo é um ato da inovação metodológica que desperta o interesse dos alunos, os quais se sentem entediados diante a praxe linear e tradicional, utilizada pelos professores da escola, fazendo com que estes assegurem a importância das aulas de campo no processo de ensino e aprendizagem, daí que:

A aula de campo proporciona ao professor o auxílio do processo de ensino e aprendizagem da Geografia, propiciando diversos elementos favorecedores ao desenvolvimento da análise e interpretação de alguns aspectos físicos geográficos, que dificilmente seriam encontrados em aulas teóricas apresentadas em sala de aula. (Entrevista com o DAP, agosto de 2019).

A aula de campo como recurso didático proporciona o desenvolvimento do conhecimento geográfico que dificilmente seria encontrado em aulas teóricas apresentadas em sala de aula, contribuindo assim, para ampliar o conhecimento geográfico e o interesse do aluno por esta disciplina escolar. Portanto, a aula de campo é de suma importância no processo de ensino e aprendizagem nas aulas de geografia e não só, pois expressa significados práticos para as aulas de geografia e dinamiza o ensino, despertando o interesse e a curiosidade pelo entendimento dos demais conteúdos geográficos, favorecendo o processo de educação geográfica.

Analisadas as considerações dos alunos e dos professores sobre a importância da aula de campo, indagamos sobre a participação e realização dessas atividades na Escola Secundária de Namialo. Com efeito, questionamos, primeiramente, aos alunos quantas vezes eles teriam participado nas aulas de campo, na disciplina de Geografia. Estes foram unânimes em dizer que nunca participaram duma aula de campo.

A falta de participação em aula de campo pelos alunos permite-nos entender que até ao final do $1^{\circ}$ trimestre de 2019 os professores de Geografia não tinham realizado nenhuma aula de campo. Este fato é confirmado pelo programa (dosificação) observado pelo autor da pesquisa no âmbito de trabalho de campo realizado na Escola Secundária de Namialo.

Quando questionamos aos professores sobre a realização das aulas de campo, esses admitiram que de fato, ainda não haviam planejado nenhuma aula de campo naquele trimestre. Confirmaram, igualmente, que têm enfrentado dificuldades na planejamento desse tipo de atividades, o que estorva a sua realização, conforme sublinhou o P3 que:

Sou professor de Geografia e leciono as $11^{\mathrm{a}}$ classes há 2 anos. Durante estes anos ainda não planifiquei nenhuma atividade relacionada a aula de campo, 
excursão geográfica ou uma visita de estudo. A não realização deve-se a vários motivos, por um lado, a negligência, por parte de nós professores da disciplina, por outro lado, envolve maior responsabilidade, deslocar alunos para outro ambiente de estudo, fora da sala de aula. Mas admito que a aula de campo é importante, principalmente na disciplina de Geografia (P3, entrevista, agosto de 2019).

Atento a esse depoimento compreende-se que os professores têm muitas limitações para realizar aulas de campo. Por um lado, persiste certo receio, e por outro lado, falta o domínio da organização de atividades como aula de campo, excursão geográfica ou visita de estudo. Seja como for, mais significativo para efeitos da análise feita nesse artigo, é o fato de que os professores reconhecem e, com efeito, ressaltam a importância da aula de campo no processo de ensino e aprendizagem de Geografia.

A realização sistemática de aulas de campo nas escolas devia ser um projeto contínuo do processo de ensino e aprendizagem, sobretudo no ensino de Geografia. Na geografia, o estudo da paisagem, do lugar, do espaço urbano, da degradação ambiental, entre outros, normalmente chegam ao aluno por meio de uma observação desenvolvida através de uma aula de campo, deixando o aluno construir o seu próprio conhecimento, conforme a sua visão e experiências de mundo. É por estas e outras razões que a introdução da prática da aula de campo na Escola Secundária de Namialo servirá como recurso complementar no processo da construção do conhecimento na disciplina de Geografia.

Ressaltamos que os professores de Geografia, tanto na escola em estudo, quanto em outras escolas secundárias devem ser dinâmicos e criativos. Para melhor resultado no desenvolvimento do conhecimento e na formação integral do aluno é de fundamental importância à utilização de novas metodologias e recursos de ensino para que o aprendizado não seja atribuído a algo chato, monótono, cansativo, pelo fato de se colocar da realidade do aluno.

A questão da realização da aula de campo devido a sua importância, para o estudo da geografia, é gratificante e significante para os professores e seus alunos, pois:

[...] como recurso didático, favorece uma participação ativa do aluno na elaboração de conhecimentos, como uma atividade construtiva que depende, ao mesmo tempo, da interpretação, da seleção e das formas de estabelecer relações entre informações. Favorece, por outro lado, a explicitação de que o conhecimento é uma organização específica de informação, sustentando tanto na materialidade da vida concreta como a partir de teorias organizadas sobre ela (SILVA; OLIVEIRA JÚNIOR, 2016, p. 3).

Portanto, a aula de campo é uma ferramenta metodológica importante para o ensino, esse é o caminho para o "desenvolvimento" do aluno, não só na escola, mas em toda a sociedade, pois ao conviver com a realidade, e podendo argumentar sobre a mesma, fazendo conexões com o teórico, torna-o um ser crítico (CALLAI, 1998).

A aula de campo é um procedimento metodológico de desenvolvimento do processo de ensino e aprendizagem, que permite ir além da simples exposição mecânica dos conteúdos em sala de aula à compreensão de uma realidade complexa de um fato ou fenómeno. Ela constitui uma estratégia didática viável no ensino de geografia, por utilizar a observação como principal técnica de investigação. 
EM

QUESTÃO

V.13 N. $03 \bullet 2020$

pág. $149-178$

\section{Um dia de campo: relato da experiência de aula de campo realizada na Escola Secundária de Namialo}

Tendo em conta as possibilidades oferecidas pelo campo para o ensino de Geografia, foi realizado a aula de campo envolvendo 4 turmas da $11^{\text {a }}$ classe da Escola Secundária de Namialo, Província de Nampula. A aula decorreu depois da $1^{\text {a }}$ fase, isto é, da aplicação do questionário e entrevista aos alunos e professores, respectivamente (figura 7).

Figura 7 - Local de concentração e ponto de partida para aula de campo na Escola de Namialo.

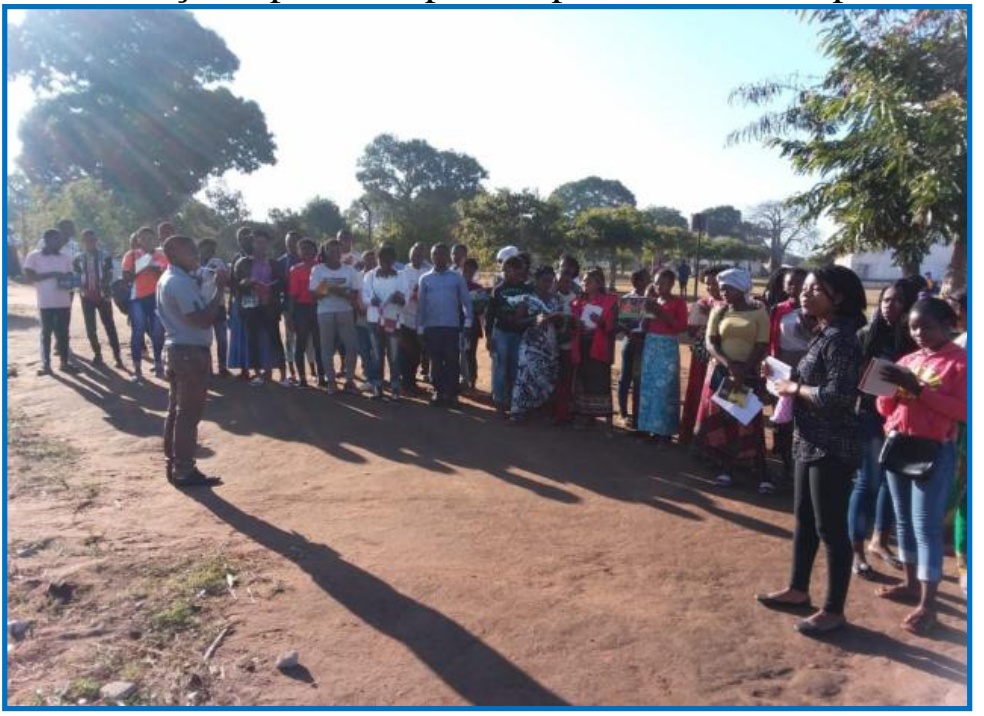

Fonte: Trabalho de campo em Namialo, agosto de 2019. Autoria: João Ntumua, 2019.

Inicialmente, fez-se um diálogo com os alunos das turmas a respeito dos conteúdos que na sequência seriam estudados buscando situá-los sobre os objetivos de aprendizagem. Depois, discutiu-se a proposta e o roteiro da aula de campo para ampliar o conhecimento dos conteúdos geográficos preestabelecidos e dar significado real aos temas tratados em sala de aula. $\mathrm{Na}$ primeira parte das atividades, foram desenvolvidas aulas teóricas na escola onde se abordou as seguintes temáticas: geomorfologia, hidrogeografia e degradação do ambiente. Tais conteúdos constam no programa de ensino de Geografia da $11^{a}$ classe; o debate sobre a degradação do ambiente aparece como conteúdos auxiliares das matérias de geomorfologia e hidrogeografia.

Assim, os conteúdos passaram a ser discutidos, primeiramente por meio de aulas expositivas, dialogadas, nas quais foi explicado aos alunos, de forma descritiva, as principais formas de relevo e dos agentes da geodinâmica externa, a dinâmica das águas dos rios e os principais problemas ambientais que perturbam o equilíbrio natural do planeta, ao mesmo tempo, eram citados alguns desses problemas que são comuns na Vila de Namialo, tais como disposição inadequada de resíduos sólidos, poluição dos recursos hídricos e desmatamento.

Depois das aulas teóricas nas quatros turmas da $11^{\text {a }}$ classe, era o momento para a aula de campo. Primeiramente, o pesquisador junto dos 3 professores de Geografia, realizaram uma visita de reconhecimento, ou seja, um pré-campo no local onde seria desenvolvida a aula de campo e, posteriormente, estabeleceram os objetivos da aula.

Uma vez definido os objetivos, assim como o percurso a ser seguido, aspectos a serem observados, horários de partida, material necessário para o estudo, enfim, questões básicas para 
evitar imprevistos que possam alterar itinerário estabelecido; era o momento da partida dos alunos ao campo de estudo.

Assim, os aspectos de natureza teórica levantados em sala de aula, relacionados ao espaço, os tipos e diferenças, são confrontadas com a paisagem vivenciada por ocasião da realização da aula de campo, cujo objetivo final era a observação do ambiente do Rio Monapo localizado na periferia da Escola Secundária de Namialo. O lugar da aula de campo foi escolhido de forma intencional por ser próximo à escola e por atender as exigências dos conteúdos lecionados em sala de aula.

Durante a concentração, assinou-se a lista de presença dos alunos, ao mesmo tempo que eram apresentados os objetivos da aula e o que deveria se ter em conta nessa observação. Na verdade, ao levar os alunos ao campo pretendia-se identificar os aspectos físicos geográficos do ambiente escolar relacionados à geomorfologia, a hidrologia e a degradação do ambiente.

O processo de observação já se inicia desde a saída da escola, e ao chegarem ao local, uma leitura visual é sugerida com base nos aspectos estudada em sala, isto é, sobre a geomorfologia: tipos de rochas e agentes da geodinâmica externa; hidrologia: dinâmica dos rios e degradação do solo para logo de seguida ser proposta uma nova leitura, sobre o meio.

Nesse sentido, chamava-se, não só a atenção dos alunos sobre a importância da preservação dos recursos geomorfológicos e hídricos para a sobrevivência da diversidade de espécies, animais e faunísticos, que correm o risco de desaparecer devido à degradação provocada pelo homem; mas também, despertar e/ou cultivar a consciência ecológica dos mesmos ao fazê-los observar e sentir, in loco, a natureza, com os seus cheiros, sons e tons, bem como os problemas induzidos pela ação humana.

À partida os alunos já estavam observando área de influência directa da ES de Namialo. No percurso os alunos constataram antes de chegar ao ponto no qual seria realizada a aula de campo três aspectos: a) o processo erosivo resultante da acção das águas pluviais e intensificado pela ação humana através da extração de areia; b) as queimadas e destruição de espécies vegetais e c) existência de rochas magmáticas na área, conforme ilustram as figuras 8, 9 e 10.

Figura 8 - Processo erosivo observado durante a aula de campo.

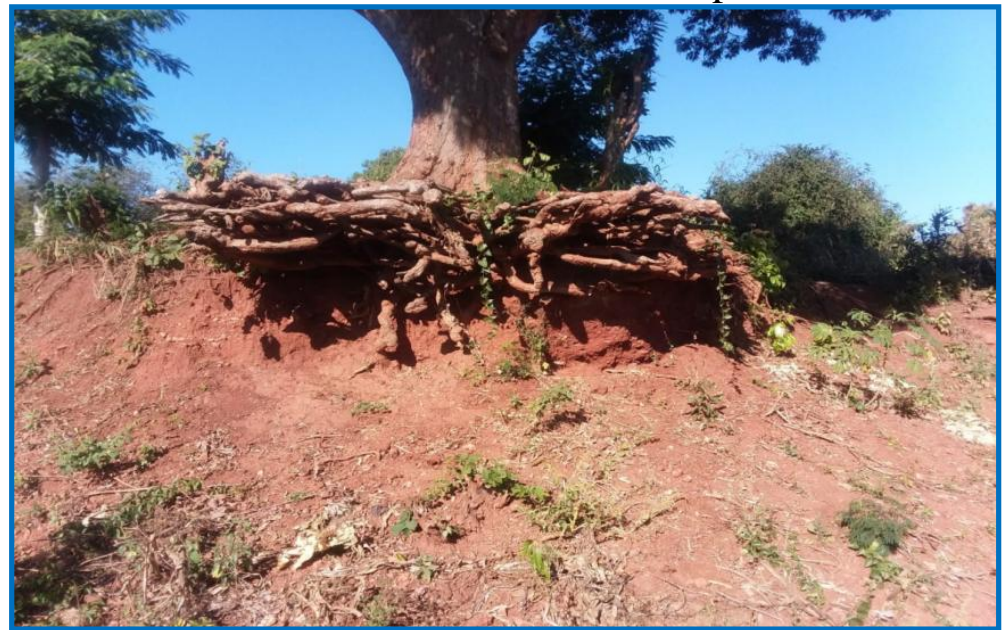

Fonte: Trabalho de campo em Namialo, agosto de 2019. Autoria: João Ntumua, 2019 
EM

QUESTÃO

V.13 N. $03 \bullet 2020$

pág. $149-178$

O processo erosivo é mais intenso no verão, por constituir o período onde a queda das chuvas é maior. A devastação das áreas pelas queimadas é também maior problema observado no Posto Administrativo de Namialo, conforme ilustra a figura 9.

Figura 9 - Área devastada por queimadas no Posto Administrativo de Namialo.

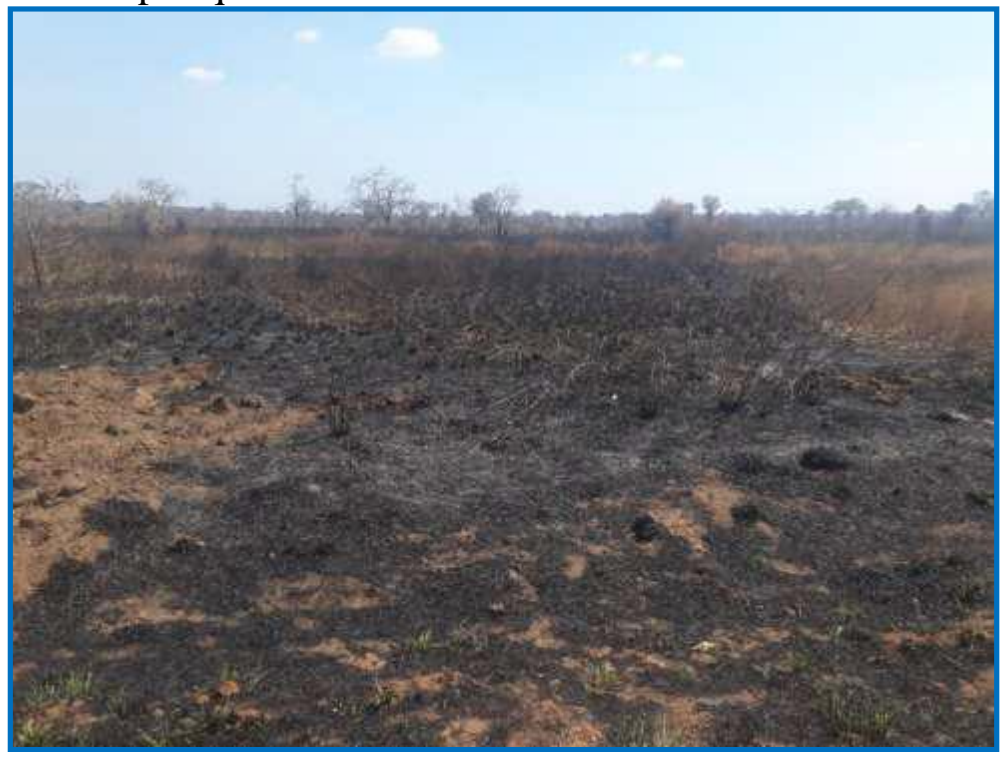

Fonte: Trabalho de campo em Namialo, agosto de 2019. Autoria: João Ntumua, 2019.

No percurso da aula de campo os alunos observaram também as rochas magmáticas, conforme ilustra a figura 10.

Figura 10 - Rochas magmáticas observadas no percurso da aula de campo.

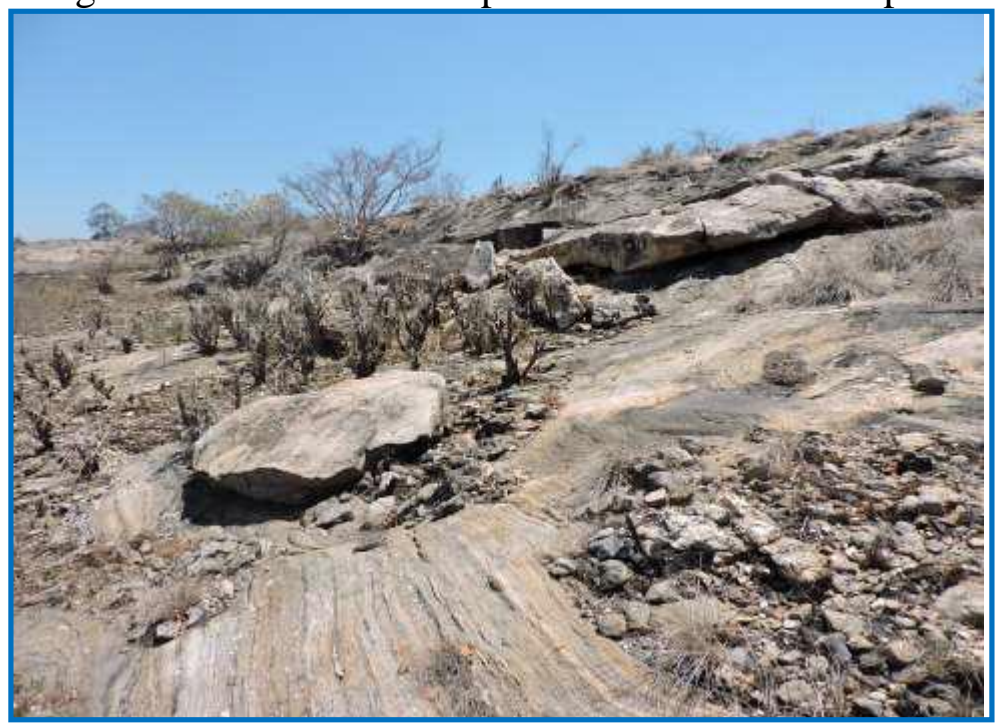

Fonte: Trabalho de campo em Namialo, agosto de 2019. Autoria: João Ntumua, 2019

As figuras ilustram a realidade do depois dos alunos observarem os aspectos do processo erosivo, queimadas resultante da ação humana e as rochas magmáticas ficaram curiosos e colocaram questões com objectivo de compreender as causas e consequências desses fatos. A 
curiosidade denota o interesse que os alunos estavam desenvolvendo pela aula de campo, pois a ciência desenvolve-se por indagações.

Ressaltamos que os professores devem ser criativos no sentido de despertar a atenção nos seus alunos e para que estes gostem e se envolvam na aprendizagem da Geografia. Nesse sentido, Almeida e Biajone (2007), defendem que é necessário reconhecer os professores como sujeitos do conhecimento, valorizando a sua subjectividade e legitimando um repertório de conhecimentos sobre o ensino, a partir do que eles são, fazem e sabem. Para tal, é necessário que os professores tenham disponíveis horas para a planificação das suas atividades, dedicadas à preparação das aulas e dos materiais necessários, isso porque, o trabalho do professor vai além do tempo em que atua em sala de aula.

No percurso da escola ao campo foi notável a ansiedade dos alunos e a curiosidade em aprender mais sobre os elementos observados. Farina e Guadagnin (2007, p. 111), lembram que "sair do ambiente escolar, por si só, gera um efeito geralmente positivo sobre o interesse dos alunos pelo conteúdo estudados".

O ponto final da nossa aula de campo foi o Rio Monapo, todos os alunos dispostos numa elevação (figura 11) observaram tudo ao seu redor, tanto os apectos geomorfológicos, hídricos e ambientais.

Os alunos mostravam maior interesse com os aspectos que iam aprendendo na aula de campo. Durante a aula várias questões foram colocadas, sobretudo aquelas relacioanadas ao ambiente hidrográfico. Tais questionamentos decorrem de observações e dos conceitos que os alunos formam durante a realização da aula de campo.

Figura 11 - Ponto de chegada de aula de campo (Rio Monapo, Namialo).

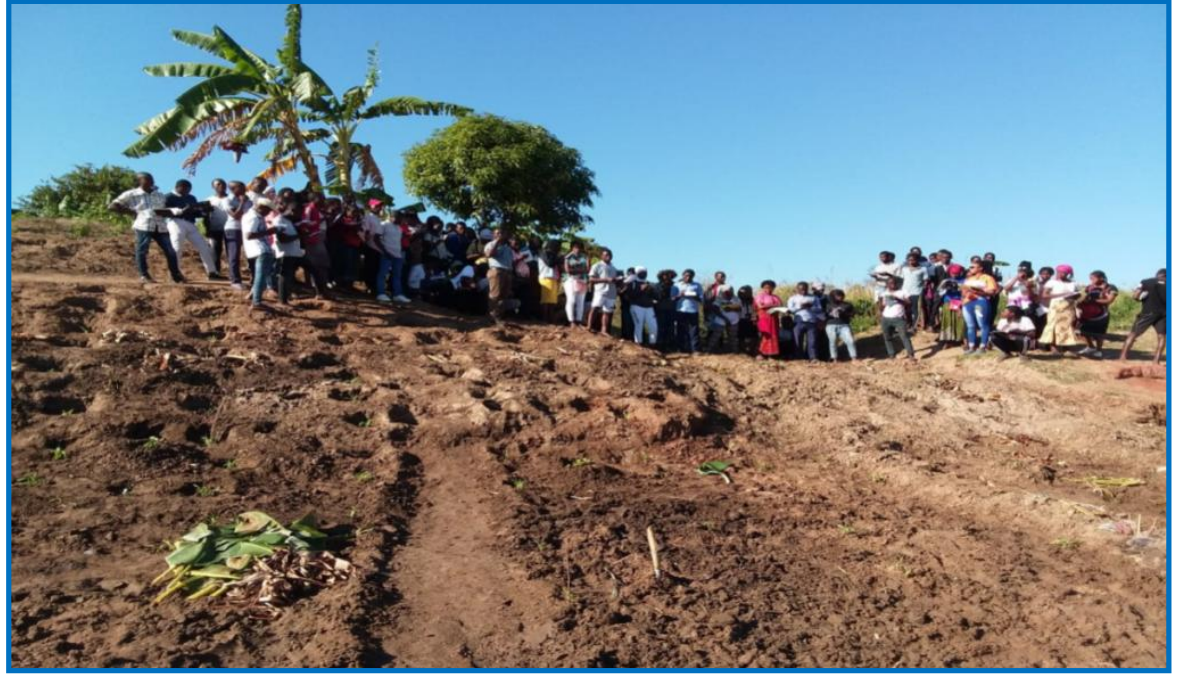

Fonte: Trabalho de campo em Namialo, agosto de 2019. Autoria: João Ntumua, 2019.

Como dissemos anteriormente, no ponto de chegada da aula de campo viveu-se um momento de aprendizagem com os alunos, um momento de pesquisa e análise que apenas uma aula de campo pode oferecer. Os alunos observaram como as águas do Rio Monapo são importantes para a comunidade local. Na senda disso, observaram também como este rio está sendo impactado pela atividade de extração de areia para a construção civil, conforme pode ser observado na figura 12 . 
Figuras 12 - Processo de extração de areia e poluição da água observado no Rio Monapo, Província de Nampula.

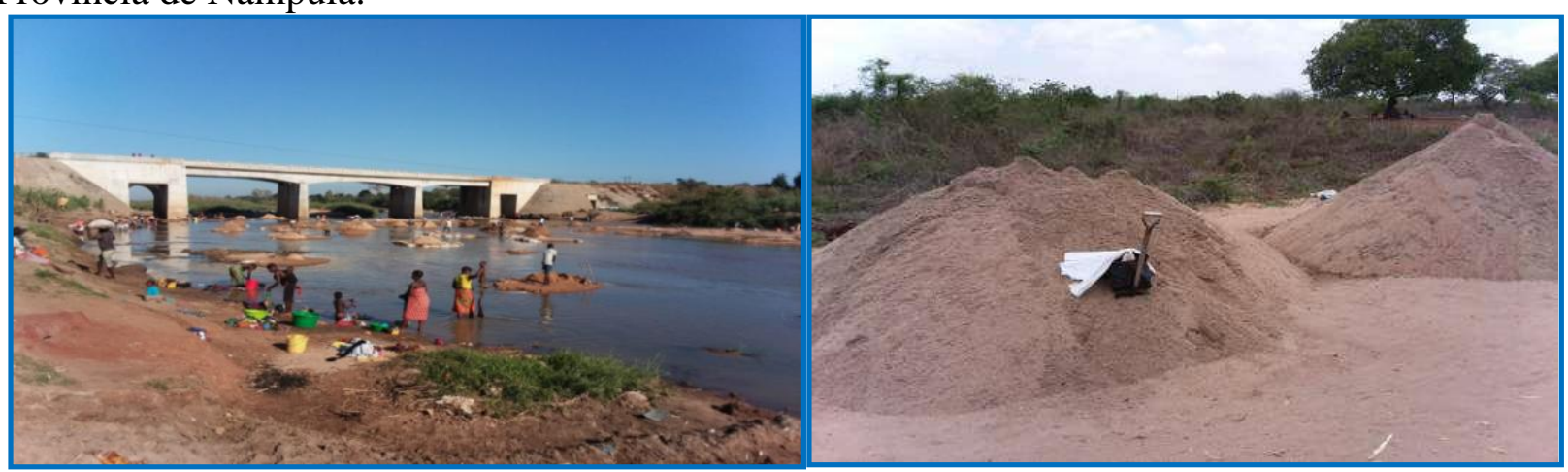

Fonte: Trabalho de campo em Namialo, agosto de 2019. Autoria: João Ntumua, 2019.

Neste ponto, os alunos compreenderam que a extração de areia apesar de benéfica para o desenvolvimento das comunidades locais, já que e uma fonte de renda, ela impacta, também o meio local. O professor explicou aos alunos que durante a extração da areia intensificam-se os processos erosivos, o que implica a poluição e/ou contaminação da água, esse fato, pode impactar negativamente a vida da população que utiliza a água deste rio para diversos fins.

Depois da observação, tanto os professores envolvidos como os alunos potencializaram os conhecimentos obtidos na sala de aula, o que ressalta a diferença entre a aula de campo e a da sala de aula, porque também as sensações fazem-se presentes no processo de apreensão dos elementos do espaço geográfico. Matheus (2007, p. 142) afirma que:

[...] É nessa perspectiva que considero importante sair do espaço escolar, mais formal, com papéis definidos e cadeiras ordenadas, para um local que nos permita desfrutar emoções, compartilhar, cantar, rir, quem sabe proporcionar um novo olhar ao que já está dado, ganhando desse modo, uma aprendizagem geográfica significativa.

Cabe ressaltar que:

[...] o trabalho de campo é benéfico e cumpre seus objetivos científicos e pedagógicos. Portanto, dizemos que ele foi utilizado para vários fins pelos povos, correntes científicas e escolas geográficas; e, cabe ao geógrafo entoar a significância dessa atividade, onde o campo é um laboratório (CARNEIRO, 2009, p. 105).

$\mathrm{Na}$ verdade, a saída ao campo constitui um elemento fundamental para dinamizar o ensino da Geografia e integrar os alunos em novos conhecimentos, pois a diversidade de elementos encontrados no espaço observado aguça a curiosidade do aluno e a aprendizagem de coisas novas, assim como favorece o diálogo e melhor relação entre professores e alunos.

Por meio dessas atividades observamos que a aula de campo desperta e/ou motiva ao aluno e contribui para aproximá-lo ao conhecimento geográfico, além de lhe permitir vivenciar aquilo que foi discutido em sala de aula, comprovando as diferenças e semelhanças da realidade geográfica dos lugares visitados, aproximando, portanto, o aluno dos temas expostos. Além disso, 
EM

QUESTÃO

pág. $149-178$

possibilita o estabelecimento de relações com outras abordagens metodológicas, como o livro didáctico.

Após a realização da aula de campo era o momento do retorno à sala de aula, onde buscamos extrair as conclusões dos alunos e ampliar os conhecimentos obtidos. Nesse sentido, foram elaboradas discussões em sala de aula com os alunos, organizados em grupos de 8 alunos, onde foram debatidos alguns elementos observados no decorrer da aula de campo. Buscou-se, desse modo, despertar a interação e o diálogo dos alunos com o professor, instigando-os a darem suas opiniões, suas críticas sobre a aula de campo (figura 13).

Figura 13 - Discussão em grupos após o retorno da aula de campo.

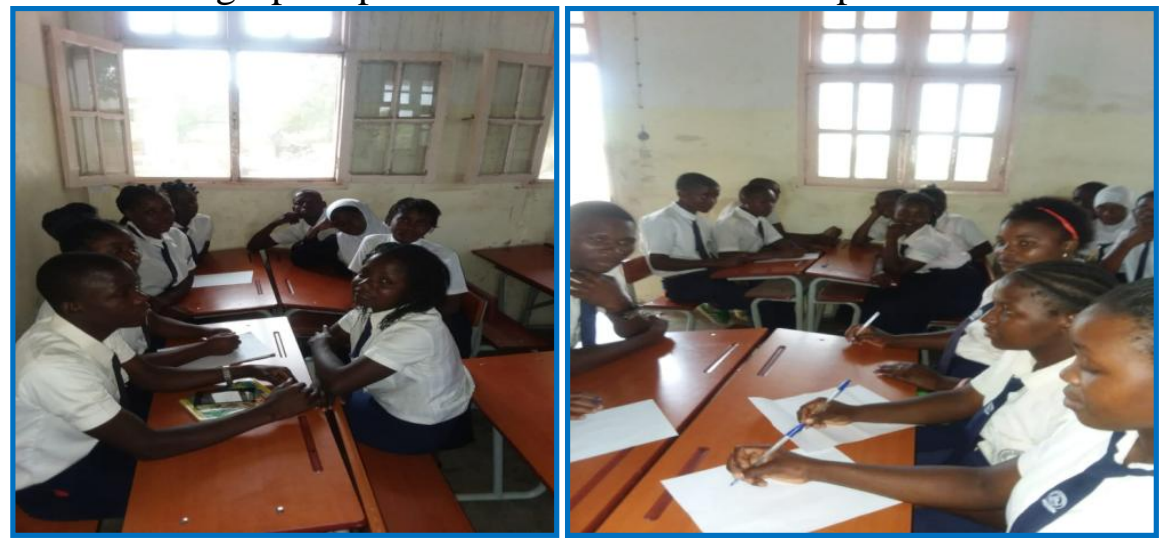

Fonte: Trabalho de campo em Namialo, agosto de 2019. Autoria: João Ntumua, 2019.

De forma ordeira foram submetidos a um breve questionário que resumiria o relatório das atividades desenvolvidas e o que eles haviam compreendido na aula de campo em relação a aula teórica transmitida em sala de aula. Nessa perspectiva, obtivemos os relatórios desenvolvidos pelos alunos que mostram as suas constatações sobre a aula de campo organizada, conforme ilustram a figura 14.

Figura 14 - Percepção dos alunos sobre a importância da aula de campo.

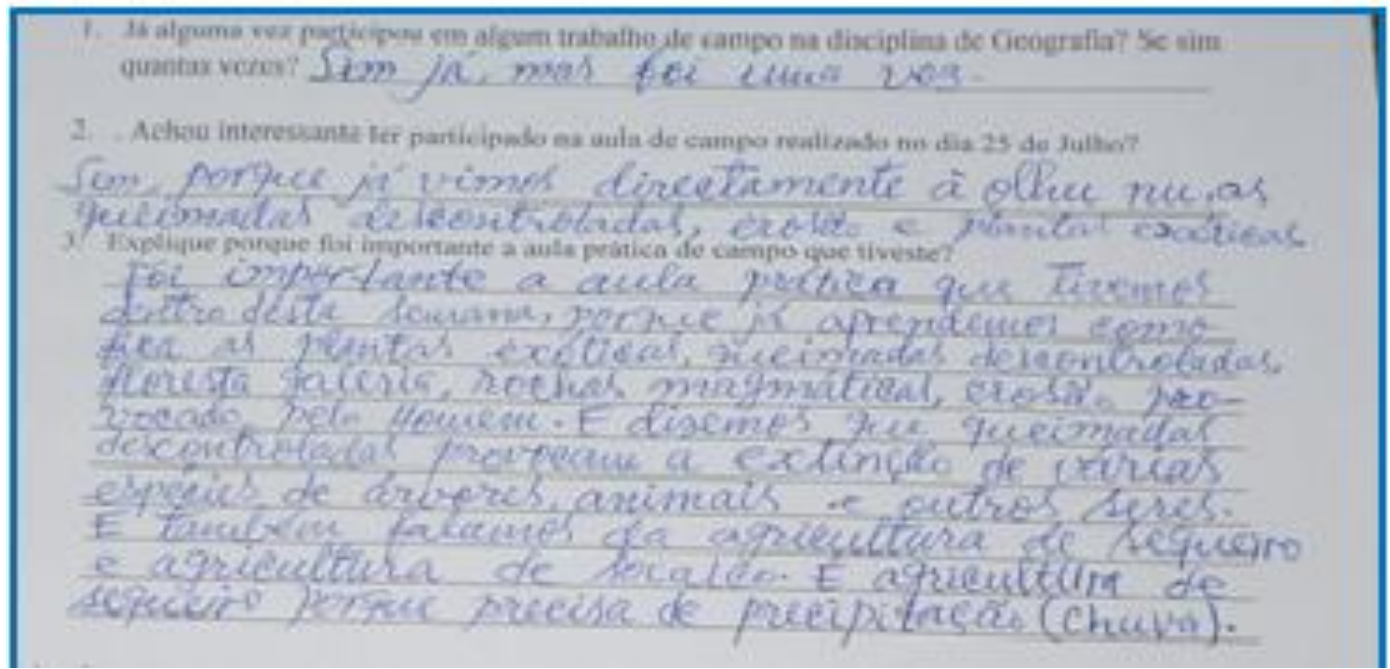

Fonte: Trabalho de campo em Namialo, agosto de 2019. Autoria: João Ntumua, 2019. 
A figura 14 ilustra parte do depoimento de alguns alunos, esses reafirmam que foi interessante a realização de aula de campo porque obtiveram conhecimentos que na sala de aula somente seriam transmitidos de forma teórica. Os alunos entendem que a erosão dos solos e a poluição das águas do Rio Monapo devem ser estudados com profundidade e, somente a aula de campo pode proporcionar esse tipo de análise.

Os alunos assinalaram também que aprenderam sobre a dinâmica das águas dos rios e a importância do uso e conservação de recursos hídricos, conforme se representa na figura 15.

Figura 15 - Comentários dos alunos sobre a importância da aula de campo na ES de Namialo.

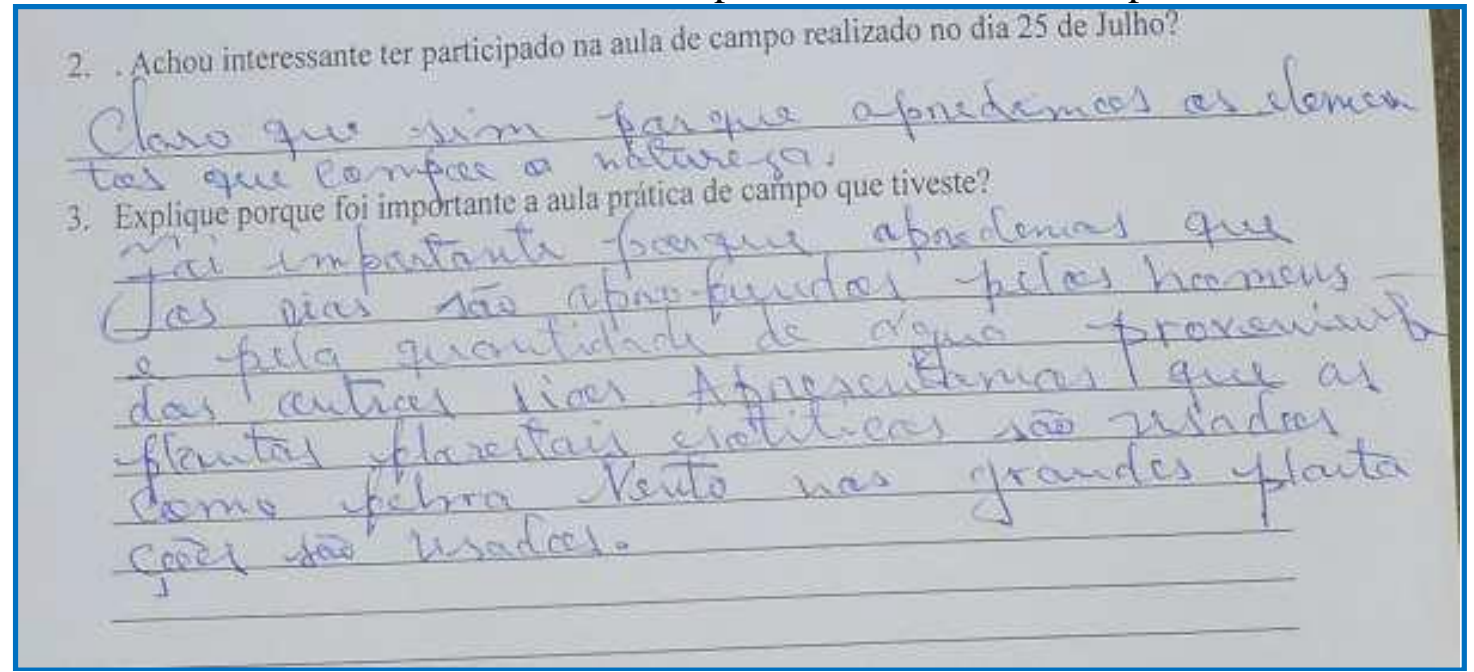

Fonte: Trabalho de campo em Namialo, agosto de 2019. Autoria: João Ntumua, 2019.

Comparando os depoimentos das figuras 14 e 15, pode-se entender que a aquisição de conhecimento nos alunos foi diversificada, enquanto os primeiros explicam com coerência sobre a importância da aula de campo, outros tiveram dificuldades em explicar o que aprenderam na aula de campo realizado no dia 25 de julho.

Apesar disso, a proposta da aula de campo na ES de Namialo, foi bem recebida pelos alunos, válida no que diz respeito ao ensino e aprendizagem dos alunos, pois assim como um outro recurso inovador, a aula de campo é importante para o ensino da geografia, já que possibilita a relação da teoria e prática, da realidade vivenciada em in loco, estudando assim a Geografia como um todo.

Com a aula de campo, as relações entre a teoria e prática tornaram-se possíveis, visto que, os alunos aprenderam sobre a geomorfologia e hidrogeografia, assim como o ambiente; no qual souberam compreender melhor os conteúdos, ativando assim seu lado investigativo e crítico. Desse modo, pode-se afirmar, que a aula dada teve um potencial muito grande já que, a disciplina de Geografia tem que ser estudada como um todo, articulada por práticas incentivadoras, que mostre de forma clara a realidade do ambiente.

De modo a compreender as preocupações dos professores, questionou-se sobre as estratégias que deviam ser desenvolvidas para o desenvolvimento do ensino de Geografia na Escola Secundária de Namialo. Em resposta a essa questão, um dos nossos entrevistados, disse:

Penso que nós como professores somos chamados a (re) pensar o processo de ensino de modo que respondamos as exigências do país, da formação de um cidadão interventivo e capaz de apoiar no desenvolvimento econômico e 
sustentável através da formação contínua das pessoas. É necessário ainda que o Ministerio de Educação e Desenvolvimento Humano (MINEDH) que tutela a educação em Moçambique se organize no sentido de trazer políticas exequíveis a educação, a motivação do professor no seu trabalho diário deve ser estimulado, de modo que o PEA seja também satisfatório (P1, entrevista, agosto de 2019).

Considerando que a aula de campo é importante, essa proposta metodológica muitas vezes não é realizada, devido aos grandes desafios a serem enfrentados. Seria necessário o apoio da parte administrativa da escola, dos pais, assim como dos Serviços Distritais de Educação e Desenvolvimento Humano (SDEDH), instituição responsável pela gestão dos processos educativos em nível dos Distritos.

É preciso lembrar que todo esforço é válido, independentemente de ser uma atividade extracurricular ou não, o professor de Geografia como intermediador do conhecimento deve buscar alternativa e mostrar que a disciplina de Geografia não é "prisioneira" de várias páginas que constitui um livro, e sim uma Geografia que, além disso, que são anos e anos de histórias, fatos e acontecimentos curiosos (COPATTI, 2017).

Já dissemos que o ensino deve ser alicerçado em um conjunto de metodologias que permitam a sua qualificação, pois:

O ensino é um processo dinâmico que envolve três elementos fundamentais: o aluno, o professor e a matéria. Os três elementos estão interligados, são ativos e participativos, sendo que a ação de um deles influencia a ação do outro. O aluno é sujeito ativo que entra no processo de ensino e aprendizagem com sua "bagagem" intelectual, afetiva e social, e é com essa bagagem que ele conta para seguir no seu processo de construção; o professor, também sujeito ativo no processo, tem o papel de mediar as relações do aluno com os objetos de conhecimento; a geografia escolar é considerada no processo como uma das mediações importantes para a relação dos alunos com a realidade (CAVALCANTI, 2010, p. 48).

Nesse sentido, o ensino da Geografia no contexto atual exige criatividade, a fim de ampliar a compreensão das dinâmicas que envolvem diferentes grupos no espaço geográfico. Consideramos, portanto, que os professores de Geografia, sobretudo em Namialo possuem um "arsenal" enorme de possibilidades para desenvolver um processo criativo em sala de aula, sendo capazes de construir, com cada turma um momento atrativo/interativo, ressignificando o processo de ensino e aprendizagem.

Copatti (2017, p. 8) descreve as principais estratégias que visam o desenvolvimento do ensino de Geografia. Nesse campo de possibilidades, o autor salienta os seguintes aspectos:

a) a criatividade, b) o uso de metodologias inovadoras e atualizadas, c) espírito de disponibilidade para inovar, d) a troca de experiência entre colegas, e) criação de redes de compartilhamento, que denominamos de grupos de disciplina, pesquisar, f) conhecer e saber utilizar recursos tecnológicos no processo educativo, g) aliar a teoria com a prática e estimular atividades interessantes, inovadoras e criativas, de acordo com a realidade do aluno.

Proporcionar atividades de interesse dos educandos em que seja desenvolvida a sua capacidade criativa é um grande desafio na atualidade. Por isso, o ensino de Geografia precisa ter 
sentido para o aluno, ou melhor, é preciso considerar a realidade do aluno, a fim de construir com ele conceitos que levem em conta o seu presente para pensar o futuro com responsabilidade (STRAFORINI, 2004).

$\mathrm{Na}$ verdade, atuar no ensino da Geografia demanda o efetivo exercício crítico e criativo, que envolve reflexões sobre nossas ações no espaço em que vivemos, possibilitando que os alunos repensem sua realidade no sentido de contribuir na reconstrução de espaços, reavaliando atitudes e propondo estratégias, para que a aprendizagem se torne significativa.

Perante os constrangimentos e desafios, cabe aos professores apostarem em estratégias que considerem a participação ativa dos alunos, tendo como objetivo maior a atenção e interação nas aulas de Geografia. A despeito desses constragimentos, destacamos a partir das constatações do trabalho de campo a importância da aula de campo, enquanto ferramenta para o desenvolvimento do processo de ensino e aprendizagem, já que permite ao aluno compreender aspectos de realidades complexas a partir de elementos empíricos, além de dinamizar o trabalho do professor e viabilizar uma articulação teórico-prática entre os conteúdos trabalhados em sala de aula e as observações sobre o lugar visitado.

\section{Desafios dos professores para realizar a aula de campo na Escola Secundária de Namialo}

O professor de Geografia na Escola Secundária de Namialo tem à sua disposição diferentes recursos que podem ser aplicados dentro (e fora) da sala de aula para auxiliar na aprendizagem do aluno e dinamizar o ensino da Geografia, tais como o trabalho com fontes documentais, imagens, estudo do meio, leitura de textos mais complexos e reflexivos, dramatizações, pesquisas, entre outros.

Assim, por meio do trabalho com abordagens metodológicas inovadoras, aliadas à utilização de diferentes recursos didáticos, o aluno percebe que os conteúdos geográficos podem ser descritos e analisados por diferentes formas de linguagem, inclusive visuais, auditivas ou de tamanho proporcional ao natural. Esse posicionamento faz com que o aluno perceba que a Geografia vai além do livro, ou de uma sala de aula, mas que a mesma pode ser presenciada em diversos meios que o próprio aluno vivencia em seu quotidiano.

Apesar de existir vários recursos didáticos no ensino de Geografia, os professores na Escola Secundária de Namialo enfrentam várias dificuldades e desafios na concretização dos seus programas de ensino. Como foi dito, a prática da aula de campo em Namialo está sendo um processo complicado, motivos já enunciados.

Quando questionado sobre as principais fontes de consulta para a planificação de suas práticas, todos recorrem ao livro didático como material principal e a internet como meios de consulta para a transmissão de conteúdos da disciplina de Geografia, sobretudo na $11^{\mathrm{a}}$ classe, foco da nossa análise.

Pretendeu-se ainda nesse momento compreender, se os professores de Geografia eram acostumados a realizar trabalhos fora de sala de aula, como a aula de campo com os alunos. Dois disseram que sim, outros três disseram que não. Para o P1 "Isso na nossa escola é inviável, não temos suporte para sair com os alunos uma vez que as salas são em média 40 a 55 alunos, precisamos de recursos e apoio da escola". Observamos que muitos professores ficam presos ao método tradicional, por medo de deixar suas práticas longe de algo inovador, como relata o P2 "Tenho medo de sair com os alunos, hoje em dia quando o professor desloca com os alunos dos 
EM

QUESTÃO

V.13 N. $03 \bullet 2020$

pág. $149-178$

seus 17, 18 anos, as pessoas compreendem como algo tendencioso"; o P3 ressaltou que "a programação de uma aula de campo dá muito trabalho".

Ressaltando a ideia o DAP2 afirmou que:

a escola não está habituada a realizar actividades fora da sala de aula, como por exemplo, aula de campo. Explicou ainda que, além da falta de fundos para custear esse tipo de evento, a aula de campo envolve um processo administrativo muito complexo a nível do Distrito, porque nenhum dos professores deve-se deslocar com os alunos sem permissão da direcção da escola e dos Serviços Distritais de Educação e Desenvolvimento Humano.

Em suma, as dificuldades enfrentadas pelos professores de Geografia na realização das suas práticas de campo, estão relacionadas, por um lado, com o suporte por meio do setor administrativo e pedagógico escolar e, por outro lado, a falta de interesse dos professores e dos pais na realização das aulas de campo.

$\mathrm{Na}$ verdade, a nossa experiência como docente permitem-nos afirmar que são inúmeras as dificuldades e desafios, enfrentadas pelos professores na realização de suas práticas, muitos justificam por não ter recursos financeiros disponíveis e por falta de apoio da escola e até mesmo da família, razões que podemos considerar não sendo plausíveis.

Quando indagados sobre a forma de avaliar seus alunos nas aulas expositivas e aulas de campo, o P1 afirmou que "não posso avaliar, pois não realizo". De principio entendemos que parcela significativa de professores fica acomodado com os métodos que utiliza, sem nenhuma vontade de buscar algo novo, isto é, inovar em suas práticas, mas tem aqueles que mesmo sem realizar a aula de campo, renova sua prática dentro da sala de aula como afirma o P4 "busco sempre que possível incentivar os alunos a trazerem nos seus argumentos algo do seu quotidiano, no sentido de aproximar-lhes da sua realidade".

Perante esses constrangimentos e desafios, cabe aos professores apostarem no desenvolvimento por meio de estratégias que considerem a participação ativa dos alunos, tendo como objetivo maior a atenção e interação nas aulas de Geografia. Para tanto, salienta-se que a criatividade do professor pode ampliar e potencializar a criatividade dos alunos, transformandoos, de certo modo, em seres mais comunicativos, sensibilizados e confiantes de suas capacidades, conscientes de sua atuação não apenas como "aprendizes", mas transformadores da realidade e do espaço onde atuam quotidianamente.

Portanto, considera-se essencial que os professores reflitam sobre o processo de ensino e aprendizagem e as necessidades dos alunos, a fim de instigar seu desenvolvimento levando em conta seus anseios, desejos e sua dimensão humana. Consideramos, ainda, que estes são seres que estão experimentando uma etapa de intensas descobertas e envoltos em inúmeras possibilidades que podem servir à aprendizagem dos alunos.

Contudo, a partir das informações obtidas vincamos que a aula de campo constitui importante ferramenta para o desenvolvimento do processo de ensino e aprendizagem, porque permite ao aluno compreender aspectos de realidades complexas a partir de elementos empíricos, além de dinamizar o trabalho do professor e viabilizar uma articulação teórico-prática, não como uma oposição, entre os conteúdos trabalhados em sala de aula e as observações sobre o lugar visitado 
EM

QUESTÃO

V.13 N. $03 \bullet 2020$

pág. $149-178$

\section{Algumas considerações finais}

Ao longo desse artigo centramo-nos na análise da aula de campo no ensino de geografia, partindo do entendimento de que ela pode ser uma estratégia metodológica útil e capaz de contribuir positivamente para o processo de ensino aprendizagem, quer instigando o aluno a olhar de forma mais crítica para a realidade que o cerca, quer levando à compreensão de que a paisagem visualizada é resultado de relações sociais, políticas e econômicas, com todas suas extensões e contradições, a qual não se manifesta concretamente. Aliás, perceber a paisagem como resultado de múltiplas relações humanas, estando em constante processo de transformação, sendo o próprio aluno (co) participante dessa dinâmica.

A Geografia escolar deve proporcionar aos alunos o conhecimento sobre a representação da paisagem, compreendendo as especificidades do espaço geográfico. Para isso, várias habilidades devem ser contextualizadas sobre o lugar do aluno, aplicando os conceitos de orientação e localização nas leituras de mapas. Observar o espaço próximo, fazer levantamentos das características desse espaço e, por meio de desafios, transferir essas características às escalas mundiais através da leitura de mapas, gráficos e figuras.

Nesse sentido, é importante sublinhar que a aula de campo pode ser utilizada como metodologia de ensino adequada para o tratamento de diferentes temáticas, já que esse método desencadeia diversos aspectos positivos, tais como a facilidade de aprendizagem, criatividade, dinamismo do PEA, relaciona a teoria com a prática, proporciona uma melhor compreensão do espaço, quebra a rotina dos estudos, motiva o interesse pela disciplina.

Apesar desse potencial, são muitas as dificuldades enfrentadas pelos professores no âmbito escolar, tanto no ensino da Geografia escolar, quanto em outras disciplinas escolares e, em razão disso, muitos discentes acabam desmotivados no ambiente educacional. Assim, cabe ao profissional da educação transformar essa realidade que tanto estorva o processo de ensino e aprendizagem por meio de adoção de alternativas, ou seja, estratégias didático - metodológicas atraentes e que cativem a atenção e o interesse do aluno pelas aulas de Geografia.

De fato, após a realização da aula de campo na Escola Secundária de Namialo, podemos afirmar que a aula de campo é um importante recurso metodológico a ser explorado nas aulas de Geografia. Entendemos, igualmente, que a aula de campo é uma atividade intencional. Embora certas ocasiões inesperadas possam ser exploradas pelo docente, acreditamos que o trabalho de campo nunca deve ser um improviso, ele deve ser elaborado a partir de um projeto de trabalho que estabeleça com clareza os conteúdos, objetivos e atividades que serão realizadas.

\section{Referências}

ALENTEJANO, P. R. R.; ROCHA-LEÃO, O. M. Trabalho de campo: uma ferramenta essencial para os geógrafos ou um instrumento banalizado? Boletim Paulista de Geografia, São Paulo, $\mathrm{n}$. 84, p. 51-67, 2006.

ANDRADE, M. C. Geografia: ciência da sociedade. Recife: EdUFPE, 2008.

ALMEIDA, P. C. A., BIAJONE, J. Saberes docentes e formação incial de professores: implicações e desafios para a proposta de formação. Campinas: EdUNICAMP, 2007. 
EM

QUESTÃO

V.13 N. $03 \bullet 2020$

pág. $149-178$

BATA, E. J. Entre estatais e transnacionais, "quantos ais": efeitos espaciais dos megaprojetos de mineração do carvão em Moatize, Moçambique. 2018. 565 f. Tese (Doutorado em Geografia) - Programa de Pós-Graduação em Geografia, Universidade Federal de Goiás, Goiânia, 2018.

CARACRISTI, I.; FONSECA, V. Os clássicos da geografia e suas contribuições para formação de professores no curso de geografia da Universidade Estadual Vale do Acaraú - UVA (SobralCE/Brasil). Revista Geográfica de América Central / XIII Encuentro de Geógrafos de América Latina, Costa Rica, edição especial, 2011. 14 p.

CARNEIRO, V. A. Concepções de trabalho de campo e ensino de geografia nas licenciaturas do Sudeste Goiano. 2009. 272 f. Dissertação (Mestrado em Geografia) - Programa de PósGraduação em Geografia, Universidade Federal de Goiás, Goiânia, 2009.

CAVALCANTI, A. P. B., VIADANA, A. G. Fundamentos históricos da geografia: contribuições do pensamento filosófico na Grécia antiga. In: GODOY, P. R. T. (Org.). História do pensamento geográfico e epistemologia em geografia. São Paulo: Cultura Acadêmica, 2008. p. 11-34.

CAVALCANTI, L. S. Geografia, escola e construção de conhecimentos. Campinas: Papirus, 2010.

COPATTI, C. O ensino da geografia na contemporaneidade e a prática docente para o despertar da criatividade. Espaço \& Geografia, Brasília, v. 20, n. 1, p. 45-67, 2017.

CALLAI, H. C. O ensino de geografia e a nova realidade. Boletim Gaúcho de Geografia, Porto Alegre, n. 24, p. 67-72, 1998.

FARINA, B. C., GUADAGNIN, F. Atividades práticas como elementos de motivação para a aprendizagem em geografia ou aprendendo na prática. In: REGO, N., CASTROGIOVANNI, A. C., KAERCHER, N. A. Geografia: práticas pedagógicas para o ensino médio. Porto Alegre: Artmed, 2007.

LANGA, J. M. R. C. Geografia de Moçambique: um olhar para a história e a epistemologia. 2017. 261 f. Tese (Doutorado em Geografia) - Programa de Pós-Graduação em Geografia, Universidade Estadual Paulista, Presidente Prudente, 2017.

LEFEBVRE, H. A produção do espaço. Paris: Editions Anthropos, 2006.

LIMA, M. H., VLACH, V. R. Geografia escolar: relações e representações da prática social. Caminhos de Geografia, Uberlândia, v. 3, n. 5, p. 44-51, 2002.

MATHEUS, E. H. C. O que há por trás de uma panela? Uma atividade de campo como trajetória a um olhar geográfico. In: REGO, N., CASTROGIOVANNI, A. C., KAERCHER, N. A. Geografia: práticas pedagógicas para o ensino médio. Porto Alegre: Artmed, 2007. 
EM

MOREIRA, R. Para onde vai o pensamento geográfico?: por uma epistemologia crítica. São Paulo: Contexto, 2012.

NASCIMENTO, A. L. Em torno do conhecimento geográfico. In: ARAUJO, L. M. (Org.). Geografia, espaço, tempo e planejamento. Maceió: EdUFAL, 2004. p. 25-42.

OMAR, A. A. Análise do ensino de geografia, na 10 $1{ }^{\text {a }}$ classe, em Moçambique, no âmbito do currículo e educação geográfica: uma abordagem centrada nas práticas de professores de geografia em quatro escolas secundárias da cidade de Nampula. 2010. 230 f. Dissertação (Mestrado em Ciências da Educação) - Instituto de Educação, Universidade do Minho, Lisboa, 2010.

SANTOS, M. Espaço geográfico. Geousp - Espaço e Tempo, São Paulo, [n. p.], 1986.

SILVA, A. F., OLIVEIRA JÚNIOR, R. J. Aula de campo como prática de ensino aprendizagem: sua importância para o ensino da geografia. São Luís: ENG, 2016.

STRAFORINI, R. Ensinar geografia: o desafio da totalidade-mundo nas séries iniciais. São Paulo: Annablume, 2004.

TRICART, Jean. O campo na dialética da geografia. Geousp - Espaço e Tempo, São Paulo, v.21, n. 1, p. 305-314, abr. 2017. 